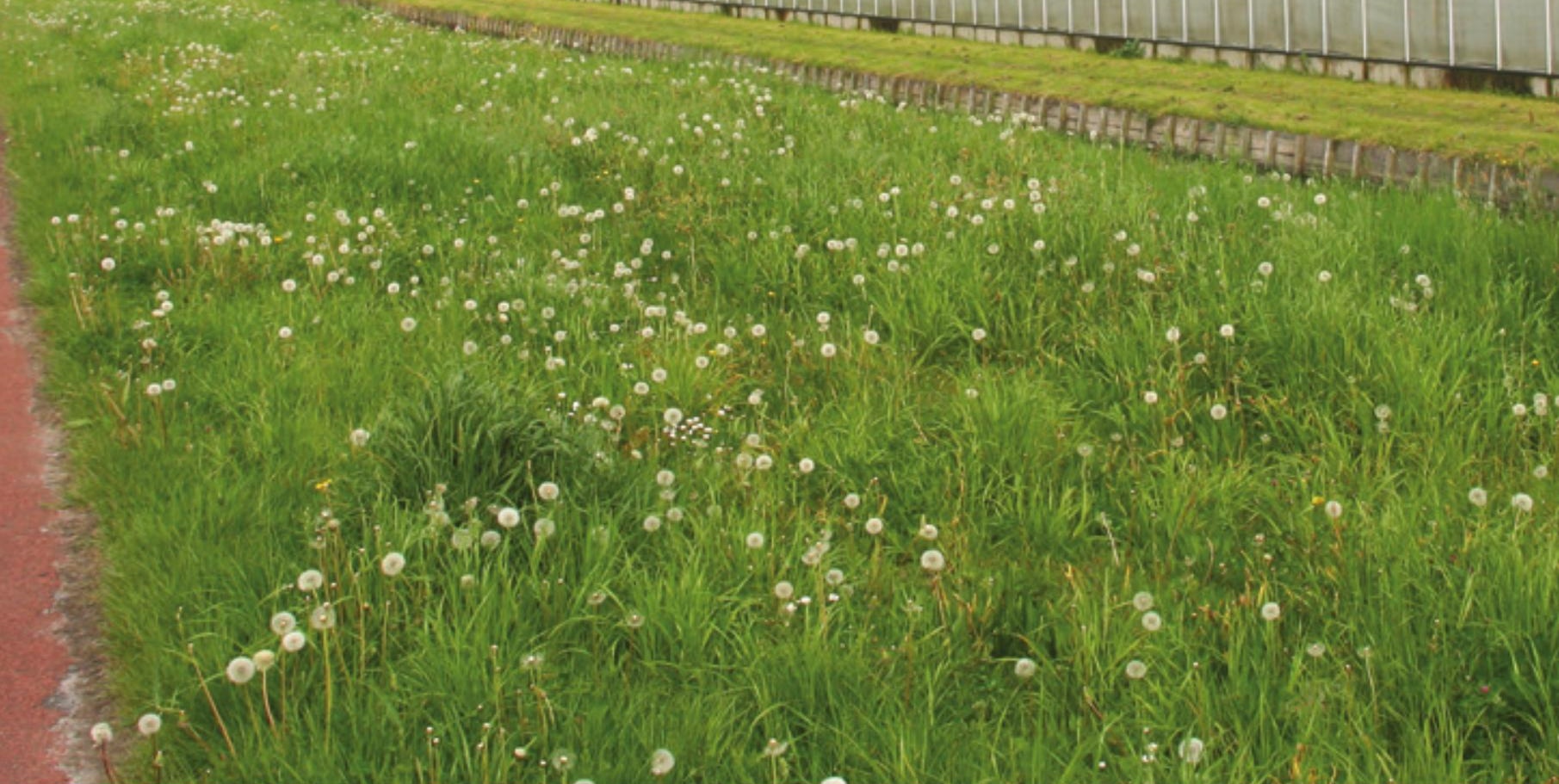

\title{
Groenbeheer en plaag(bestrijdende) insecten nabij kassen in de gemeente Westland
}

Carla Grashof-Bokdam, Gerben J. Messelink, Wim Ozinga, Renata van Holstein-Saj, Chantal Bloemhard, Joop Woelke, Henk Meeuwsen 



\section{Groenbeheer en plaag(bestrijdende) insecten nabij kassen in de gemeente Westland}

Carla Grashof-Bokdam ${ }^{1}$, Gerben J. Messelink ${ }^{2}$, Wim Ozinga ${ }^{1}$, Renata van Holstein-Saj ${ }^{2}$, Chantal Bloemhard ${ }^{2}$, Joop Woelke ${ }^{2}$, Henk Meeuwsen ${ }^{1}$

1 Wageningen Environmental Research

2 Wageningen Plant Research

Dit onderzoek is uitgevoerd door Wageningen Environmental Research in opdracht van de gemeente Westland en gefinancierd door de gemeente Westland, het Hoogheemraadshap van Delfland en de Provincie Zuid-Holland. (projectnummer 5200044538).

Wageningen Environmental Research

Wageningen, april 2019

Gereviewd door:

Wim Dimmers en Ruud van Kats, functie HBO onderzoeker entomologie

Akkoord voor publicatie:

Nina Smits, teamleider Vegetatie, Bos- en Landschapsecologie

Rapport 2946

ISSN 1566-7197 
Carla Grashof-Bokdam, Gerben J. Messelink, Wim Ozinga, Renata van Holstein-Saj, Chantal Bloemhard, Joop Woelke, Henk Meeuwsen, 2019. Groenbeheer en plaag(bestrijdende) insecten nabij kassen in de gemeente Westland. Wageningen, Wageningen Environmental Research, Rapport 2946. 48 blz.; 12 fig.; 13 tab. ; 2 ref.

In dit project is gekeken naar het effect van regulier beheer in bermen ten opzichte van natuurlijk beheer in de Poelzone in de gemeente Westland op de populaties van plaaginsecten, hun natuurlijke vijanden en waardplanten van deze groepen. Locaties in de Poelzone zijn, vergeleken met regulier beheerde bermen, iets rijker in soorten waardplanten, natuurlijke vijanden, plagen en neutrale herbivore soorten. Het gevonden aantal individuen van alle plaagsoorten trips is veel lager dan dat van alle neutrale herbivore soorten, maar totale aantallen zijn hoger in regulier beheerde bermen. Plaagsoorten en -bestrijders komen op uiteenlopende bemonsterde soorten waardplanten voor, vaak op dezelfde plantensoorten. Het aantal monsters met natuurlijke vijanden van trips en bladluizen lijkt tegelijkertijd zijn maximum te bereiken met het aantal monsters van de plaagsoorten die ze bestrijden. De gevonden populatie plaag(bestrijdende) soorten wijkt niet af in oevers, maar bemonsterde locaties in oevers hebben relatief wat meer vroegbloeiende waardplanten. In de onderzochte locaties in de Poelzone met natuurlijk beheer lijkt een iets beter evenwicht tussen plaagsoorten en natuurlijke plaagbestrijders te bestaan dan in de onderzochte regulier beheerde bermen, maar de verschillen zijn klein en beide beheertypen voorkomen niet dat er überhaupt plaagsoorten aanwezig zijn. Er zijn aanbevelingen gedaan voor vervolgonderzoek.

In this project the effect of regular maintenance of road-verges and natural maintenance of the "Poelzone" on populations of pestinsects, their natural enemies and host plants has been studied. In the studies locations in the Poelzone the number of hostplants, natural enemies, pest species and neutral herbivores is slightly higher than in the regular managed road verges. The number of pest thrips individuals is lower than the number of neutral thrips species, but total numbers of thrips are higher in the regular managed verges. Pest species and natural enemies have been found on various host plant species, often on similar species. Thrips species and their natural enemies reach their maximum occurrence simultaneously. The studied locations along water banks have similar insect populations but are relatively rich in early flowering species. The studies locations in the Poelzone seem to have a slightly better balance between pest and regulating species compared to locations in regular managed road verges, but differences are small and in both management types pest species have been found. Suggestions for further research have been presented.

Dit rapport is gratis te downloaden van https://doi.org/10.18174/476301 of op www.wur.nl/environmental-research (ga naar 'Wageningen Environmental Research' in de grijze balk onderaan). Wageningen Environmental Research verstrekt geen gedrukte exemplaren van rapporten.

(9) 2019 Wageningen Environmental Research (instituut binnen de rechtspersoon Stichting Wageningen Research), Postbus 47, 6700 AA Wageningen, T 03174807 00, www.wur.nl/environmental-research. Wageningen Environmental Research is onderdeel van Wageningen University \& Research.

- Overname, verveelvoudiging of openbaarmaking van deze uitgave is toegestaan mits met duidelijke bronvermelding.

- Overname, verveelvoudiging of openbaarmaking is niet toegestaan voor commerciële doeleinden en/of geldelijk gewin.

- Overname, verveelvoudiging of openbaarmaking is niet toegestaan voor die gedeelten van deze uitgave waarvan duidelijk is dat de auteursrechten liggen bij derden en/of zijn voorbehouden.

Wageningen Environmental Research aanvaardt geen aansprakelijkheid voor eventuele schade voortvloeiend uit het gebruik van de resultaten van dit onderzoek of de toepassing van de adviezen.

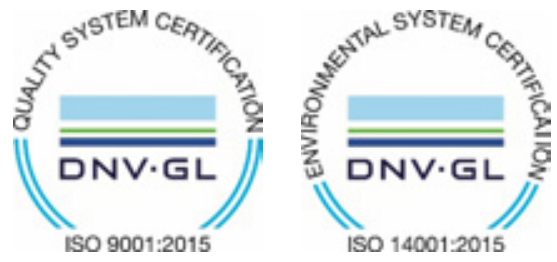

Wageningen Environmental Research werkt sinds 2003 met een ISO 9001 gecertificeerd kwaliteitsmanagementsysteem. In 2006 heeft Wageningen Environmental Research een milieuzorgsysteem geïmplementeerd, gecertificeerd volgens de norm ISO 14001.

Wageningen Environmental Research geeft via ISO 26000 invulling aan haar maatschappelijke verantwoordelijkheid.

Wageningen Environmental Research Rapport 2946 | ISSN 1566-7197

Foto omslag: Shutterstock 


\section{Inhoud}

$\begin{array}{ll}\text { Verantwoording } & 5\end{array}$

$\begin{array}{ll}\text { Samenvatting } & 7\end{array}$

1

$\begin{array}{ll}\text { Inleiding } & 9\end{array}$

1.1 De vraag 9

1.2 Doel van het onderzoek 9

$\begin{array}{lll}1.3 \text { Werkwijze } & 10\end{array}$

2

$\begin{array}{ll}\text { Methode } & 11\end{array}$

2.1 Keuze locaties $\quad 11$

2.2 Groen in de omgeving van Poelzone en bermen 13

$\begin{array}{lll}2.3 & \text { Monitoring waardplanten en plaaginsecten } & 14\end{array}$

3

$\begin{array}{ll}\text { Resultaten } & 16\end{array}$

3.1 Groen in de omgeving van bermen en Poelzone 16

3.2 Belangrijkste soorten plaaginsecten en plaagbestrijders in Poelzone en bermen 18

3.3 Voorkomen waardplanten in Poelzone en bermen 23

3.4 Perioden van voorkomen plaagbestrijdende en plaagsoorten 26

$\begin{array}{lll}3.5 & \text { Aanvullende waarnemingen } & 28\end{array}$

3.6 Perioden van voorkomen plaaginsecten in Poelzone, bermen en kassen 30

$\begin{array}{lll}4.1 & \text { Conclusies } & 31\end{array}$

4.2 Discussie $\quad 32$

4.3 Aanbevelingen $\quad 34$

$\begin{array}{ll}\text { Dankwoord } & 35\end{array}$

$\begin{array}{ll}\text { Literatuur } & 36\end{array}$

Bijlage 1 Samenvatting insecten en locaties $\quad 37$

Bijlage 2 Waardplanten in bermen en Poelzone 39

$\begin{array}{lll}\text { Bijlage } 3 & \text { Insecten en waardplanten } & 45\end{array}$ 



\section{Verantwoording}

Rapport: 2946

Projectnummer: 5200044538

Wageningen Environmental Research (WENR) hecht grote waarde aan de kwaliteit van onze eindproducten. Een review van de rapporten op wetenschappelijke kwaliteit door een referent maakt standaard onderdeel uit van ons kwaliteitsbeleid.

Akkoord Referent die het heeft beoordeeld,

functie: $\quad \mathrm{HBO}$ onderzoeker entomologie

naam: Wim Dimmers en Ruud van Kats

datum: $\quad$ 04-04-2019

Akkoord teamleider voor de inhoud,

naam: Nina Smits

datum: $\quad$ 04-04-2019 


\section{Samenvatting}

In dit onderzoek willen we een antwoord vinden op de vraag wat het effect is van regulier beheer ten opzichte van natuurlijk beheer in wegbermen en/of (natte) ecologische zones in de gemeente Westland op de populaties van plaaginsecten, hun natuurlijke vijanden en waardplanten van deze insecten. Daartoe zijn de vegetatie en de insectenpopulatie bemonsterd op vier locaties in de Poelzone, die natuurlijk beheerd wordt door de gemeente, en op vier locaties in regulier beheerde bermen. Van de locaties in bermen worden er twee beheerd door de gemeente (Julianaweg) en twee door de provincie (N211). Op de locaties zijn transecten van $50 \mathrm{~m}$ bemonsterd, op locaties die langs het water liggen zijn twee transecten bemonsterd, één in de oever en één op de heuvel (Poelzone) of in het droge deel van de berm. De monitoring is uitgevoerd door Wageningen Environmental Research en Wageningen Plant Research, tussen april en augustus 2018. De insecten zijn vijf keer bemonsterd (bloem- en vangnetmonsters) en de vegetatie drie keer. Daarnaast zijn enquêteformulieren aan tuinders verstrekt via LTO Glaskracht om informatie te verzamelen over plaagsoorten die in dezelfde periode zijn aangetroffen in omliggende kassen. Van elke locatie is de hoeveelheid groen binnen een straal van $1 \mathrm{~km}$ in kaart gebracht om te bepalen of verschillen in insectenpopulaties eventueel veroorzaakt kunnen worden door verschillen in type en oppervlakte leefgebied in de omgeving.

Het groen in de omgeving is voor de locaties P3 en P4 iets afwijkend van de andere onderzochte locaties in de Poelzone (P1 en P2), maar dit lijkt nauwelijks invloed te hebben op de soortensamenstelling van insecten in het onderzochte gebied.

Er komen heel veel verschillende soorten natuurlijke plaagbestrijders, plaagsoorten, neutrale herbivore soorten voor in onderzochte locaties in de regulier beheerde bermen en in de Poelzone. In de Poelzone komen meer plantensoorten voor en hier zijn ook meer (bloem)monsters en dus iets meer soorten insecten verzameld. Dit zijn vooral soorten natuurlijke vijanden en neutrale herbivore soorten, maar ook plaagsoorten. Het aantal monsters met natuurlijke vijanden, plaagsoorten en neutrale herbivore soorten verschilt relatief gezien nauwelijks tussen de Poelzone en bermen. Wel zijn er minder individuen van trips, vooral Thrips physapus en Thrips tabaci (Tabakstrips) in de Poelzone gevonden. Dit kan te maken hebben met de hogere aanwezigheid van Orius niger, een belangrijke roofwants van trips, in de Poelzone. In zowel Poelzone als regulier beheerde bermen maken plaagsoorten qua aantallen individuen een klein deel uit van de hele populatie trips, die vooral uit neutrale herbivore, dus onschadelijke soorten bestaat. Dit lijkt ook te gelden voor bladluis en bijbehorende natuurlijke vijanden, ook uit losse waarnemingen. Dit is belangrijk, omdat neutrale herbivore soorten een voedselbron vormen voor natuurlijke vijanden van plaagsoorten. De populatie plaag(bestrijdende) soorten in oevers en op oeverplanten wijkt nauwelijks af van de rest van de Poelzone.

Zowel natuurlijke plaagbestrijders als plaagsoorten komen veel voor op bemonsterde algemene plantensoorten die vaak lang bloeien, maar ook op later of juist vroegbloeiende plantensoorten. Vooral de onderzochte locaties in oevers van de Poelzone hebben een aantal vroegbloeiende plantensoorten, waardoor er het hele seizoen aanbod van voedsel en schuilgelegenheid is voor insecten.

De hoogste dichtheden van zowel Frankliniella occidentalis (Californische trips) als de natuurlijke vijand Orius niger werden in juli bereikt in de onderzochte locaties. Voor bladluizen en hun natuurlijke vijanden is het seizoensbeeld wat minder duidelijk, maar ook hier lijken de natuurlijke plaagbestrijders en plaagsoorten gelijktijdig hun maximale dichtheden te bereiken.

We hebben van één kas gegevens ontvangen over plagen en bestrijding in 2018. Dit vonden we onvoldoende om waarnemingen in kassen te vergelijken met waarnemingen in bermen en Poelzone. 
Concluderend lijkt er in de onderzochte locaties in de Poelzone (met natuurlijk beheer) een iets beter evenwicht te bestaan tussen plaagsoorten en natuurlijke plaagbestrijders dan in de onderzochte bermlocaties (met regulier beheer). De verschillen zijn echter klein en beide beheertypen voorkomen niet dat er überhaupt plaagsoorten voorkomen. Er zijn aanbevelingen gedaan voor vervolgonderzoek. Aanbevelingen voor beheer zijn nog lastig te geven, gezien het feit dat dit onderzoek zich beperkt tot één gebied en één seizoen, het aantal herhalingen per waardplant klein zijn en het aantal monsters per locatie verschilt. 


\section{$1 \quad$ Inleiding}

\subsection{De vraag}

In de gemeente Westland wordt (door gemeente, provincie en hoogheemraadschap) een natuurlijker beheer van bermen en andere groene elementen beoogd en daarmee een grotere diversiteit aan planten en dieren. Dit wordt bereikt door de vegetaties minder vaak en later te maaien, zodat planten in bloei kunnen komen en zaad kunnen vormen en insecten er kunnen schuilen en er voedsel kunnen vinden. De biodiversiteit in bermen en andere elementen draagt ook bij aan de kwaliteit van het woonmilieu van veel mensen, binnen en buiten de bebouwde kom.

Dit beheer heeft een positief effect op de biodiversiteit in de gemeente, maar het roept ook vragen op bij burgers en leidt tot zorgen bij tuinders met kassen. De discussie met tuinders draait om de vraag of natuurlijk beheerde vegetaties een bron van insecten en eventueel ongewenste kruiden zijn die een plaag in de kassen kunnen vormen, terwijl kort gemaaide vegetaties dat wellicht niet zijn.

Het hoogheemraadschap, zo mogelijk in samenwerking met gemeenten, legt natte ecologische zones aan (o.a. natuurvriendelijke oevers en vispaaiplaatsen) ten behoeve van een goede ecologische waterkwaliteit. Om met deze oeverzones een ecologisch netwerk te kunnen realiseren, is het nodig om ook kansen te benutten nabij glastuinbouwbedrijven. De eigenaren van deze glastuinbouwbedrijven hebben vaak bezwaren tegen de aanleg van deze natte ecologische zones, omdat ze vrezen voor negatieve effecten (bron van plaaginsecten en onkruidzaden) hiervan op hun teelten in de naastgelegen kassen.

\subsection{Doel van het onderzoek}

In dit onderzoek willen we een antwoord vinden op de vraag of vegetaties met een natuurlijk beheer in wegbermen en/of ecologische zones in het groeiseizoen een grotere bron van plaaginsecten in kassen kunnen vormen dan regulier beheerde vegetaties. Bij plaagsoorten denken we vooral aan trips, maar we willen in principe alle soorten plaaginsecten inventariseren die relevant zijn voor de kasteelt. Anderzijds willen we ook vaststellen welke natuurlijke vijanden we aantreffen in genoemde vegetaties en hoe het voorkomen van plaagsoorten en natuurlijke vijanden zich tot elkaar verhoudt. Een evenwichtige populatie aan insecten kan een positieve bijdrage leveren aan natuurlijke plaagbestrijding.

Daarbij willen we de volgende vragen beantwoorden:

- Welke (waard)planten van plaaginsecten en natuurlijke vijanden treffen we aan in een berm met een natuurlijk maaibeheer en welke in een regulier beheerde berm?

- Welke rol speelt de natte ecologische zone (Poelzone), die natuurvriendelijke oevers heeft en ook een natuurlijk maaibeheer kent, in de samenstelling van plantensoorten en de aanwezigheid van plaagsoorten en natuurlijke vijanden?

- Welke plaagsoorten en natuurlijke vijanden treffen we aan in de Poelzone en bermen?

- Zijn dit dezelfde plaagsoorten en natuurlijke vijanden als aangetroffen/ingezet worden in kassen in de nabije omgeving?

- Zo ja, komen deze plaagsoorten en natuurlijke vijanden in de geïnventariseerde bermen en Poelzone in dezelfde perioden voor als de plaagsoorten/natuurlijke vijanden in de omliggende kassen, zodat natuurlijke vijanden ook daadwerkelijk de plaagsoorten kunnen bestrijden?

- Is het voorkomen van plaagsoorten en natuurlijke vijanden gerelateerd aan de ligging van kassen en/of leefgebied in de nabije omgeving? 
Daarnaast willen we eventuele vervolgvragen formuleren die uit dit project naar voren komen. Het beantwoorden van deze vragen maakt geen deel uit van het project. Mogelijke vervolgvragen kunnen zijn:

- Bewegen plaagsoorten (en natuurlijke vijanden) zich van bermen en Poelzone naar kassen en/of van kassen naar bermen en Poelzone en hoe kan dit plaatsvinden?

- Welke invloed heeft dit op de productie van gewassen in glastuinbouwbedrijven?

- Heeft ecologisch beheer van groenzones effect (via aanwezigheid schadelijke insecten) op de productie van gewassen? Indien deze negatief zijn, wat zijn dan mogelijke oplossingen om deze negatieve invloed te verzachten of op te heffen?

\section{$1.3 \quad$ Werkwijze}

Met natuurlijk groenbeheer van bermen en ecologische zones streven de diverse beheerders (zowel gemeente, provincie als hoogheemraadschap) naar versterking van biodiversiteit, daarom is er in het beheer een afweging nodig tussen algehele biodiversiteit van o.a. planten en insecten, waaronder natuurlijke vijanden van plaagsoorten en de aanwezigheid van plaagsoorten als trips. Dit onderzoek moet vooral duidelijk maken of in de natuurlijk beheerde vegetaties vaker waardplanten en plaaginsecten voorkomen die ook in de kassen in de omgeving worden aangetroffen dan in regulier beheerde vegetaties. Ook moet dit onderzoek duidelijk maken of in deze vegetaties ook natuurlijke vijanden van plaagsoorten voorkomen die kunnen voorkomen dat plaagsoorten schade aan gewassen veroorzaken. Daarnaast moet het aangeven of deze plaaginsecten en natuurlijke vijanden alleen in de natuurlijk beheerde vegetaties gevonden worden of ook in regelmatig gemaaide bermen. Als natuurlijk beheerde variant is gekozen voor de natte ecologische zone (Poelzone), aangezien het hoogheemraadschap de rol van oevers graag mee wil laten nemen in het onderzoek. Daarnaast is er nog geen natuurlijk beheerde provinciale berm voorhanden in de gemeente.

Als er in bermen en Poelzone plaagsoorten worden aangetroffen die overeenkomen met die in de kassen, wordt vervolgens ook gekeken naar het tijdstip van uitbraken in de bermen en Poelzone en vergeleken met die in de kas. Dit kan beter met een variant met vijf vangrondes dan met een variant met twee vangrondes. Dit geldt ook voor natuurlijke vijanden die in bermen aangetroffen worden en evt. natuurlijke vijanden die ingezet worden in de kas. Voor de vegetatie zijn drie inventarisatierondes voldoende.

Als zowel de soorten als het tijdstip van soorten in de Poelzone en de bermen overeenkomen met die gevonden in de kassen is waarschijnlijk nader onderzoek nodig of insecten vanuit de kas in de bermen en de Poelzone terechtkomen of juist van de bermen en de Poelzone naar de kas bewegen. Vervolgens kan gekeken worden of en welke maatregelen nodig zijn om mogelijke inwaai van plaagsoorten in de kassen te voorkomen of effecten van natuurlijke vijanden beter te benutten.

Om de vragen bij 1.2 te beantwoorden, zijn de volgende stappen genomen:

1. Keuze van vier locaties in bermen en in de Poelzone waarin waardplanten en insecten worden geïnventariseerd, met onderscheid in oevers en droge delen waar mogelijk.

2. Inventariseren waardplanten (drie rondes) en bemonsteren insecten (vijf rondes) van april tot augustus 2018.

3. Vergelijken type en hoeveelheid groen binnen $1 \mathrm{~km}$ van elke locatie om vast te stellen of een andere groensamenstelling de populatie insecten en waardplanten beïnvloed kan hebben.

4. Bepalen belangrijkste soorten plaaginsecten en plaagbestrijders in Poelzone en bermen, met speciale aandacht voor oevers.

5. Bepalen belangrijkste waardplanten voor plaagbestrijders en plaaginsecten in de Poelzone en de bermen, met speciale aandacht voor oevers.

6. Vaststellen van perioden van voorkomen plaag bestrijdende en plaagsoorten.

7. Aanvullende waarnemingen insecten en waardplanten beschrijven.

8. Vergelijken perioden voorkomen van plaaginsecten in Poelzone, bermen en omliggende kassen. 


\section{$2 \quad$ Methode}

\section{$2.1 \quad$ Keuze locaties}

In het overleg van 8 januari 2018 met de WUR, gemeente Westland, Provincie Zuid-Holland, Hoogheemraadschap van Delfland, LTO Glaskracht en een aantal tuinders rond de Poelzone is de ecologische verbindingszone gekozen als natuurlijk beheerde berm (Poelzone), omdat hier ecologisch beheer wordt toegepast en omdat er ook oeverzones aanwezig zijn. Op de tweede bijeenkomst van 6 februari zijn de bermen langs de provinciale weg N211 genoemd als kandidaat voor de gemaaide berm. Deze zal dan gedurende de onderzoeksperiode nog geklepeld worden en niet ecologisch beheerd zoals in andere provinciale bermen al wordt gedaan.

Beide locaties moeten in de omgeving van kassen liggen (straal $1000 \mathrm{~m}$ ) die last denken te hebben van plaaginsecten en/of onkruidzaden uit bermen. Omdat de provinciale weg op veel plekken vrij smal is, is besloten om ook langs de Julianaweg twee locaties te zoeken die representatief zijn voor regulier gemaaide bermen. Waar locaties langs watergangen liggen, is onderscheid gemaakt tussen opnames in de berm (of op heuvels in de Poelzone) en in de oever. Er zijn acht locaties gekozen, vier in de Poelzone, twee langs de N211 en twee langs de Julianaweg. Zes van de locaties hebben een oever langs de berm (tabel 2.1, figuur 2.1):

Tabel 2.1 Ligging en beschrijving proeflocaties.

\begin{tabular}{llllll} 
Gebied & Plothr & Plek & X & y & \\
Poelzone & P1 & oever & 70955 & 448388 & tussen fietspad en oever \\
\hline Poelzone & P2 & oever & 71082 & 448318 & tussen wandelpad en oever \\
\hline Poelzone & P3 & heuvel & 71116 & 448227 & boven op heuvel achter bank langs achterkant \\
\hline Poelzone & P4 & heuvel & 71489 & 448199 & boven op heuvel \\
\hline berm & oever & 71704 & 448211 & langs wandelpad en fietspad \\
\hline berm & B1 & heuvel & 71693 & 448187 & boven op heuvel \\
\hline berm & berm & 70957 & 447881 & stukje bos tot aan inrit boerderij bij lantaarnpaal \\
\hline berm & B4 & bever & 70667 & 448360 & van lantaarnpaal tot inrit boerderij \\
\hline & berm & 70657 & 448363 & van begin veldje tot aan inrit boerderij \\
\hline & & berm & 70538 & 448383 & vanaf kastje ten zuiden van rotonde 50 m naar het \\
\hline
\end{tabular}


Tabel 2.2 Beheer proeflocaties.

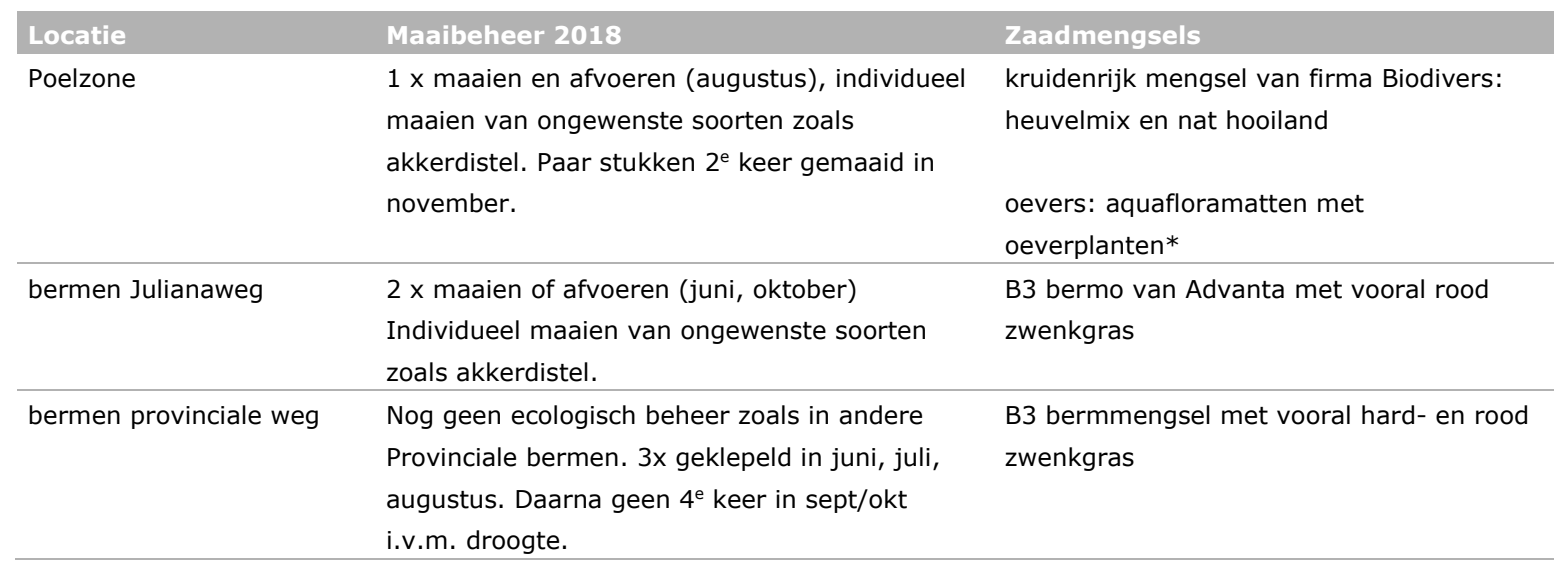

*: In de vispaaiplaatsen zijn op de onder ribben Heen, Grote 'Waterweegbree, Grote Egelskop, Gele Lis, Gewone Waterbies, Moerasandoorn, Moeraszegge, Oeverzegge, Zwanenbloem, Watermunt en mogelijk ook Mattenbies en Scherpe Zegge aangebracht. In de vrije diepere delen van de paaiplaatsen en natuurvriendelijke oevers zijn Witte Waterlelie, Gele Plomp en/of Watergentiaan aangebracht.

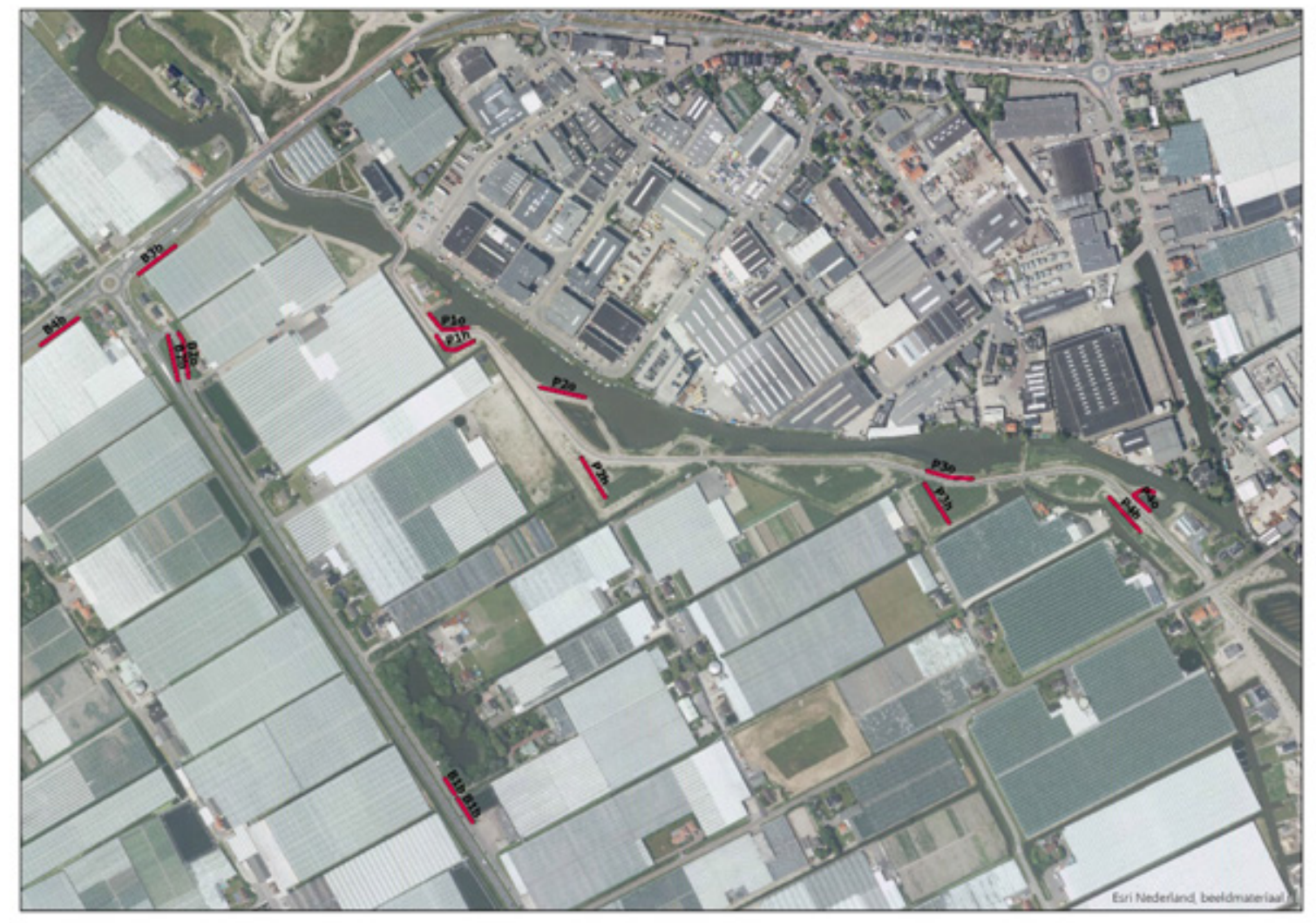

Figuur 2.1 Ligging proeflocaties op de topografische kaart. 

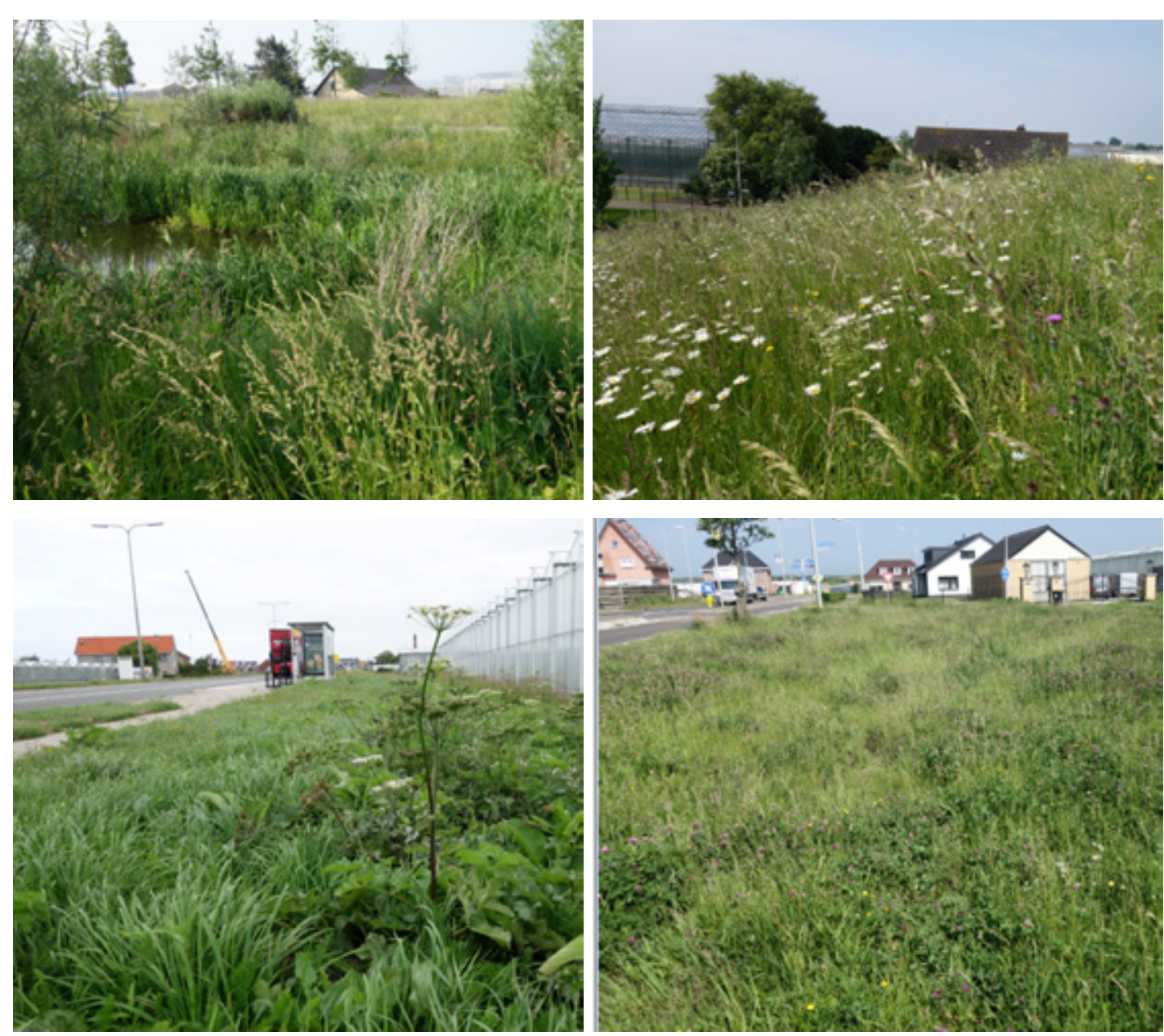

Figuur 2.2 Ecologische bermen in de Poelzone (linksboven oever en rechtsboven heuvel) en een berm met standaard maaibeleid (linksonder provinciale weg, rechtsonder Julianaweg) in juni 2018.

\subsection{Groen in de omgeving van Poelzone en bermen}

Met behulp van GIS wordt ook de omgeving (tot $1000 \mathrm{~m}$ ) van beide locaties (ecologische zone en gemaaide berm) geanalyseerd, waarbij de hoeveelheid en ligging van groene elementen uit digitale bestanden worden afgeleid. Hierbij worden groene elementen in kaart gebracht die kunnen dienen als habitat voor plaagsoorten en plaagbestrijdende soorten. Dit is van belang, omdat de aanwezigheid van insecten niet alleen wordt bepaald door het type beheer van de ecologische zone of berm zelf, maar ook door potentiële leefgebieden in de omgeving.

Voor de ligging en classificatie van het grondgebruik wordt in eerste instantie gebruikgemaakt van de Basisregistratie Grootschalige Topografie (BGT), versie 2017. Dit bestand is op het gebied van plantsoenen, wegen, wegbermen, sloten en slootkanten veel gedetailleerder dan Top10NL (onderdeel van de Basisregistratie Topografie, BRT). De BGT bevat hier en daar vlakken die zijn geclassificeerd als 'transitie', hetgeen betekent dat bij de opbouw van het bestand het grondgebruik nog niet bekend was. Ook worden in de BGT andere inwinningscriteria gehanteerd waardoor bijvoorbeeld eenheden groen op erven niet zijn meegenomen, terwijl die wel in Top10NL opgenomen zijn. Daarom wordt relevant groen uit Top10NL (versie 2017) dat valt binnen de typen 'transitie' en 'erf' ook meegenomen in de analyse. Daarnaast worden ook bomenrijen en heggen uit Top10NL meegenomen, want die ontbreken in de BGT. Een van de vlakken die in de BGT als 'transitie' is geclassificeerd, is het meest zuidelijke deel van de Poelzone. Aangezien deze zone tijdens de inwinning van de recentste versie van Top10NL nog niet uitontwikkeld was, is hij als 'overig' geclassificeerd. Het is mogelijk om binnen deze zone op basis van de luchtfoto onderscheid te maken tussen water en land (hoofdzakelijk kaal zand) en dat als zodanig te digitaliseren. 
De typen groen uit de BGT en Top10NL zijn geaggregeerd tot de typen "duinen", "gras", "groenvoorziening", "oever", "struiken" en "bosplantsoen". Rondom elke proeflocatie is binnen een buffer van $1000 \mathrm{~m}$ bepaald hoeveel (oppervlakte) van deze typen groen er aanwezig is.

\subsection{Monitoring wardplanten en plaaginsecten}

$\mathrm{Er}$ is een enqueteformulier gemaakt om informatie in te winnen over waargenomen plagen in de kas en genomen maatregelen rond plaagbestrijding in 2018. Deze is via LTO Glaskracht verspreid onder tuinders die hebben aangegeven mee te willen werken aan het onderzoek.

Op elke locatie (zowel berm/heuvel als oever) wordt langs een transect van $50 \mathrm{~m}$ de vegetatie en de voorkomende plaag(bestrijdende) insecten geïnventariseerd. Binnen deze $50 \mathrm{~m}$ is een vrij brede strook geïnventariseerd op planten en hun bijbehorende insecten: langs de oevers van de Poelzone tot aan het fietspad, op de heuvels over de breedte van de kruin en langs de bermen over de gehele breedte. Bij het inventariseren met een vangnet wordt een strook van ongeveer $2 \mathrm{~m}$ breed bemonsterd. De vegetatie-inventarisatie is drie keer herhaald (april, juni, augustus) en de insecteninventarisatie is vijf keer herhaald (april, mei, juni, juli, augustus) om een indruk te krijgen van de seizoeneffecten op het voorkomen van insecten en hun waardplanten. De drie vegetatierondes zijn samen uitgevoerd met de insecteninventarisatie in die maand.

In principe inventariseren we zo veel mogelijk (bloeiende) planten in de Poelzone en in bermen en inventariseren we plaag(bestrijdende) insecten zo uitgebreid mogelijk. Voor een eerste indruk van de vegetatie is gekeken naar de inventarisatie van de lokale KNNV-afdeling uit 2017 (Nonhof, 2017). Op beide locaties worden de volgende gegevens verzameld:

Vegetatie:

- vegetatiesamenstelling (soort(groep)en abundantie) m.b.v. een tansley-opname (figuur 2.3 ) in elke locatie (oever, berm of heuvel);

- van elke locatie zijn foto's gemaakt tijdens de drie inventarisatierondes;

- kruiden en grassen zijn consequent meegenomen, mossen niet;

- de vegetatieopnamen zijn ingevoerd in het vegetatiedataverwerkingsprogramma Turboveg (Hennekens \& Schaminee, 2001).

Insecten:

- Er zijn van de meest voorkomende bloeiende planten bloemmonsters verzameld en in alcohol gestopt in potjes van $135 \mathrm{ml}$. Daarnaast zijn monsters genomen op elke locatie met een vangnet (diameter $35 \mathrm{~cm}$ ) waarmee elk transect van $50 \mathrm{~m}$ over een breedte van $2 \mathrm{~m}$ is bemonsterd gedurende enkele minuten.

- De volgende groepen insecten worden via bloemmonsters en met het vangnet verzameld:

- vliegende natuurlijke vijanden van de volgende groepen: Orius niger, miride roofwantsen, coccinellidae (lieveheersbeestjes), zweefvliegen, gaasvliegen;

- bloembewonende roofmijten (niet vliegend);

- vliegende plaaginsecten: witte vlieg, bladluis, miride wantsen, stinkwantsen, trips onderverdeeld in soorten (per soort(groep) aantallen tellen).

- Verder zijn planten visueel beoordeeld op aanwezigheid van plagen en natuurlijke vijanden, dit geldt voor:

- mijten die passief met wind migreren: spintmijten;

- larven die uitgekweekt worden tot het adulte stadium voor determinaties: rupsen en mineervlieg;

- larven en poppen van natuurlijke vijanden die uitgekweekt worden tot het adulte stadium voor determinaties: sluipwespen van rupsen, bladluis, mineervlieg, witte vlieg en galmuglarven;

- bladluiskolonies.

- De gevangen soort(groep)en insecten zijn in het laboratorium geteld en op naam gebracht. Determinaties van tripsen zijn gecontroleerd door tripsexpert Bert Vierbergen van de NVWA. 


\begin{tabular}{|c|c|c|}
\hline symbool & abundantie en frequentie & $\begin{array}{l}\text { numerieke } \\
\text { transformatie }\end{array}$ \\
\hline s & $\begin{array}{l}\text { sporadic, sparse, de soort is zeer zeldzaam, slechts enkele exemplaren } \\
\text { aanwezig }\end{array}$ & 1 \\
\hline $\mathbf{r}$ & rare, de soort is zeldzaam & 2 \\
\hline$\circ$ & $\begin{array}{l}\text { occasional, de soort wordt zo nu en dan aangetroffen en is verspreid } \\
\text { aanwezig }\end{array}$ & 3 \\
\hline If & locally frequent, plaatselijk frequent & 4 \\
\hline f & frequent, de soort wordt frequent aangetroffen en is vrij talrijk & 5 \\
\hline la & locally abundant, plaatselijk talrijk & 6 \\
\hline a & abundant, de soort is talrijk, veel aanwezig maar nooit (co-)dominant & 7 \\
\hline Id & locally dominant, plaatselijk overheersend & 8 \\
\hline $\begin{array}{l}c(\text { od }) \\
\text { d }\end{array}$ & $\begin{array}{l}\text { codominant, de soort is overheersend samen met andere soorten } \\
\text { dominant, de soort is overheersend }\end{array}$ & 9 \\
\hline
\end{tabular}

Figuur 2.3 Abundantieklassen Tansley.

Informatie uit de kassen wordt ingewonnen via formulieren die door LTO zijn voorgelegd aan zes bedrijven:

- selectie van kassen die meedoen in de analyse in gebieden binnen $750 \mathrm{~m}$ tot $1 \mathrm{~km}$ van zowel de te inventariseren ecologische zone en gemaaide berm;

- locatie kassen op kaart;

- type teelt in deze kassen;

- plaagdruk en plaagperiode trips en andere insecten (soorten \& abundantie);

- gebruikte methode plaagbestrijding (biologisch welke soorten/chemisch).

Van de verzamelde informatie over de vegetatiesamenstelling wordt van relevante soorten (groep) de rol bepaald als waardplant voor plaaginsecten/of natuurlijke vijanden. Hiertoe zijn de vegetatiedata uit Turboveg geëxporteerd naar Excel. De insectendata zijn ook ingevoerd in Excel. In Excel zijn data van insecten en bloemmonsters gekoppeld aan de waargenomen (bloem)planten. Per locatie in de bermen en in de Poelzone is een overzicht gemaakt van welke insectensoorten op welke waardplanten zijn gevonden en wanneer. In de monitoring in de Poelzone (P1 t/m P4) en in twee bermen (B1 en B2) is onderscheid gemaakt in oevers en heuvels/bermen. 


\section{Resultaten}

\subsection{Groen in de omgeving van bermen en Poelzone}

In de onderstaande figuren $3.1 \mathrm{a} \mathrm{t} / \mathrm{m} \mathrm{f}$ zijn per categorie groen de verschillen weergegeven in de oppervlakte groen in de nabije omgeving (binnen $1 \mathrm{~km}$ ) tussen natuurlijk beheerde bermen (Poelzone) en regulier beheerde bermen (Provinciale weg en Julianaweg). De figuren zijn weergegeven van typen groen met het grootste areaal (duin) naar het kleinste areaal (bos) (figuur 3.1).

a) Duin:

$2.636 .565 \mathrm{~m}^{2}=264 h a$

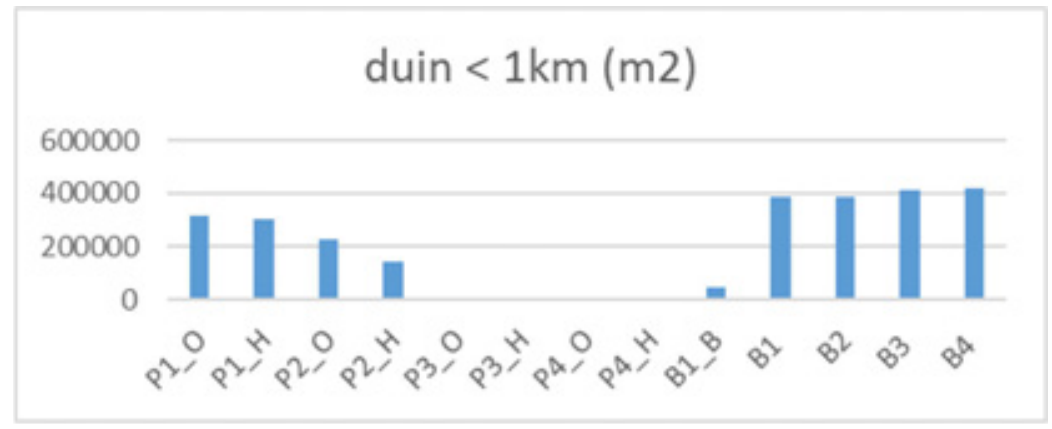

b) Gras:

$2.474 .954 m^{2}=247 h a$

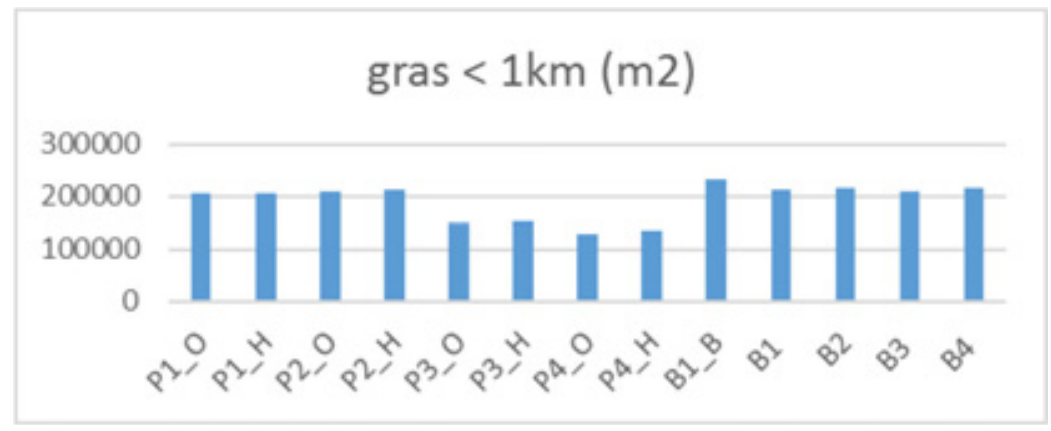

c) Groenvoorziening: $877.749 \mathrm{~m}^{2}=88 \mathrm{ha}$

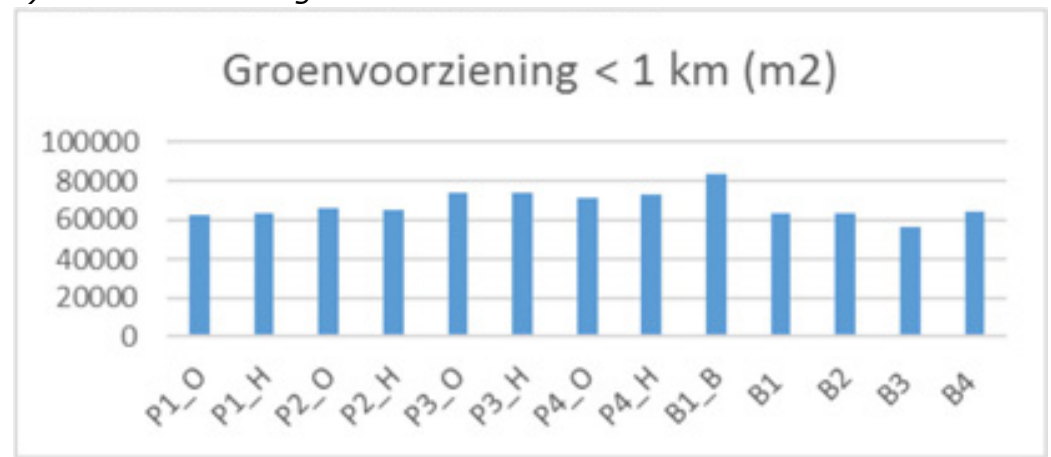




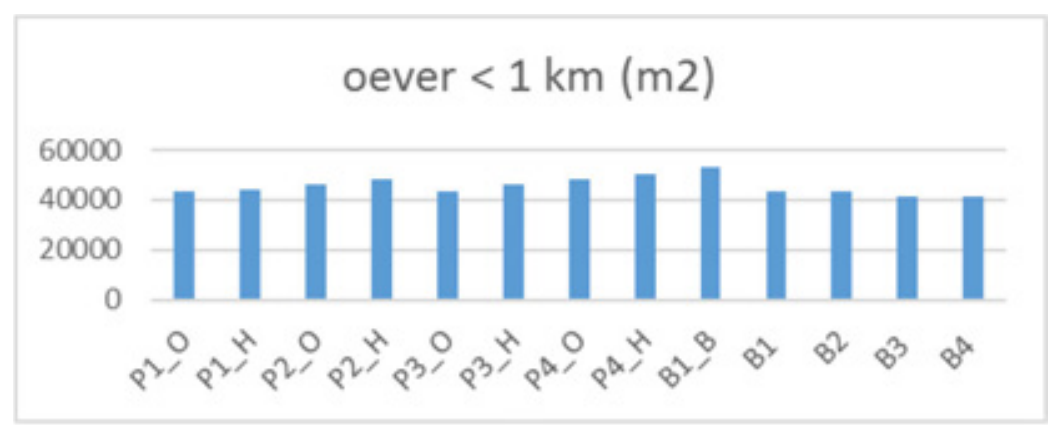

e) Struiken:

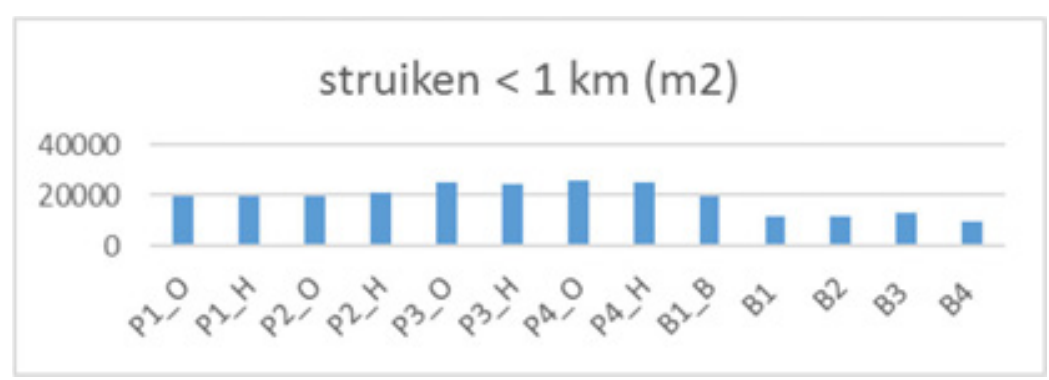

\section{f) Bosplantsoen: $\quad 56.035 \mathrm{~m}^{2}=5.6 \mathrm{ha}$}

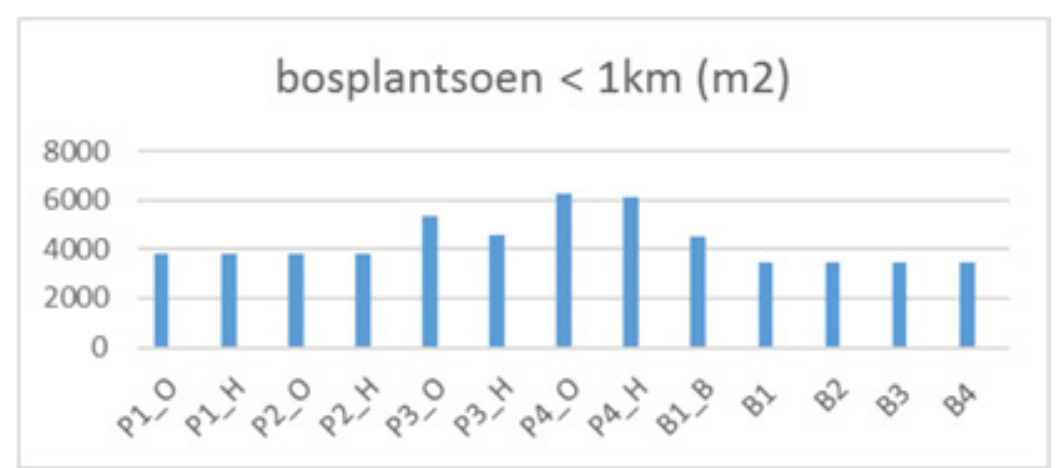

Figuur 3.1 Aantal hectares per type groen per locatie. De figuren zijn gerangschikt in volgorde van totaalaantal ha: a) duinen, b) gras, c) groenvoorziening, d) oever, e) struiken, f) bosplantsoen. $\mathrm{O}=$ oever, $\mathrm{H}=$ heuvel.

Bij de classificatie van duinen zijn alle soorten duin (open en gesloten) samengenomen. Duinen en gras maken het grootste deel uit van het aanwezige groen binnen $1 \mathrm{~km}$ rond de geïnventariseerde vegetaties. Daarna komen groenvoorziening, oevers, struiken en bos heeft de kleinste oppervlakte. Er is hierbij weinig onderscheid tussen oeverlocaties en droge locaties van de Poelzone, omdat deze erg dicht bij elkaar liggen.

B1 tm B4 hebben het grootste areaal duin in de nabije omgeving en P3 en P4 het minst. Na duinen is gras het meest voorkomende type groen. Dit is grotendeels geclassificeerd als transitie. Daarnaast komt gras vooral voor in (weg)bermen. Bij locatie P3 en P4 komt minder gras in de buurt voor dan bij de andere locaties. Groenvoorziening komt vooral langs wegen voor, maar er is geen informatie over waar deze groenvoorziening uit bestaat. P3 en P4 lijken iets meer groenvoorziening in de buurt te hebben dan de andere locaties. P3 en P4 hebben ook iets minder oppervlakte aan oevers in de nabije omgeving. Struiken bestaan vooral uit heesters, P3 en P4 hebben iets grotere arealen struiken en bosplantsoen in de omgeving. 


\subsection{Belangrijkste soorten plaaginsecten en plaagbestrijders in Poelzone en bermen}

In tabel 3.1a, b en $\mathrm{c}$ is het aantal monsters weergegeven waarin een bepaalde soort( $\mathrm{groep}$ ) is aangetroffen. Het totale aantal verzamelde monsters (bloemhoofdjes en vangnetmonsters) is 199, 62 in de regulierbeheerde bermen en 137 in de Poelzone.

Tabel 3.1a Aantal verzamelde monsters warin plaagbestrijdende soorten zijn aangetroffen. Resultaten van individuele soorten zweefvliegen, lieveheersbeestjes en gaasvliegen zijn weergegeven in tabel 3.1b.

\begin{tabular}{|c|c|c|c|c|c|c|c|c|c|c|c|c|}
\hline Plaagbestrijders & Prooi & B1 & B2 & B3 & B4 & Btot & P1 & P2 & P3 & P4 & Ptot & totaal \\
\hline $\begin{array}{l}\text { Cantharis livida } \\
\text { (roofkever) }\end{array}$ & divers & & & & & & & & 10 & 10 & 2 & 2 \\
\hline $\begin{array}{l}\text { Praon volucre } \\
\text { (sluipwesp) }\end{array}$ & bladluis & & & & & & 10 & & & & 1 & 1 \\
\hline $\begin{array}{l}\text { Orius niger } \\
\text { (roofwants) }\end{array}$ & trips & $3 b$ & $11 b$ & $1 b$ & & 15 & 8 ho & 17 ho & 18ho & 14 ho & 57 & 72 \\
\hline $\begin{array}{l}\text { Phytoseiidae } \\
\text { (roofmijten) }\end{array}$ & trips & $3 b$ & $1 b$ & $1 b$ & $2 b$ & 7 & 20 & 5 ho & 20 & 30 & 12 & 19 \\
\hline $\begin{array}{l}\text { lieveheersbeestje } \\
\text { (7 soorten) }\end{array}$ & bladluis & 5 & 4 & 2 & 2 & 13 & 4 & 9 & 9 & 4 & 26 & 39 \\
\hline $\begin{array}{l}\text { gaasvlieg } \\
\text { ( } 2 \text { soorten) }\end{array}$ & $\begin{array}{l}\text { bladluis } \\
\text { divers }\end{array}$ & 0 & 2 & 1 & 3 & 6 & 2 & 0 & 2 & 1 & 5 & 11 \\
\hline
\end{tabular}

$\mathrm{o}=$ in oever

$\mathrm{h}=$ op heuvel (poelzone)

$\mathrm{b}=$ in berm

Veel natuurlijke vijanden komen zowel in bermen als in de Poelzone voor, maar in de Poelzone zijn iets meer soorten gevonden. Cantharis livida (Geel soldaatje), Aphidoletes aphidimyza (een galmug en bestrijder van bladluis), Praon volucre (sluipwesp van bladluis) en Nabis sp. (generalistische roofwants) komen voornamelijk in oevers van de Poelzone voor, maar slechts in enkele monsters (figuur 3.2a). Orius niger, Phytoseiidae (roofmijten) en lieveheersbeestjes zijn in meer monsters aangetroffen in de Poelzone dan in regulier beheerde bermen, maar in de Poelzone zijn ook ruim twee keer zoveel monsters verzameld (137) dan in de bermen (62). Orius niger is de enige soort die ook relatief gezien duidelijk in meer monsters voorkomt in de Poelzone dan in de bermen. Orius niger komt, net als Phytoseiidae, zowel in bermen, heuvels als in oevers voor. 
Tabel 3.1b Aantal verzamelde monsters waarin plaagbestrijdende soorten zijn aangetroffen. Resultaten van individuele soorten zweefvliegen, lieveheersbeestjes en gaasvliegen.

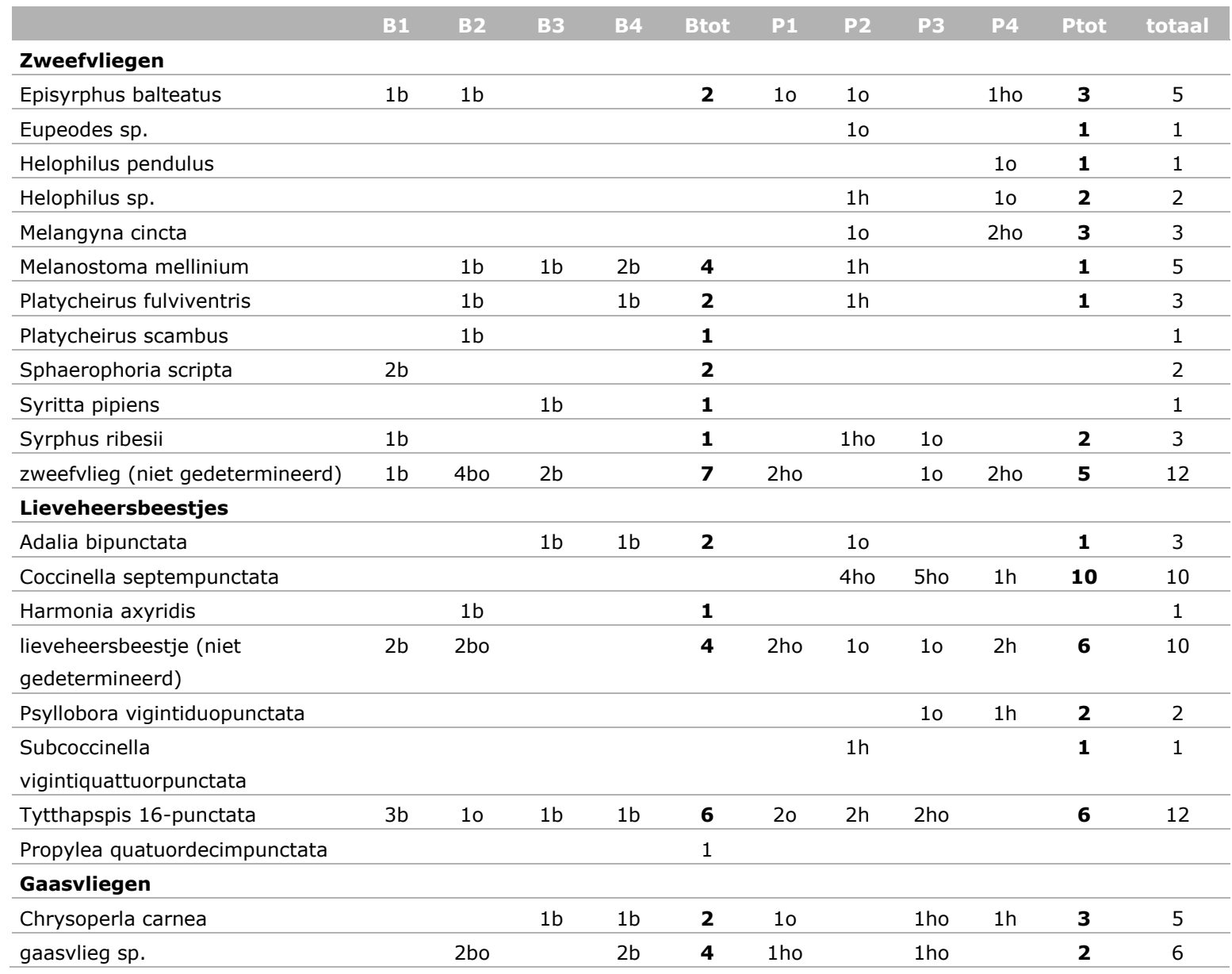

$0=$ in oever

$\mathrm{h}=$ op heuvel (poelzone)

$\mathrm{b}=$ in berm

Sommige soorten zweefvliegen komen meer voor in de Poelzone (zowel in oevers als op heuvels), andere meer in drogere delen van regulier beheerde bermen en weer andere hebben geen duidelijke voorkeur (figuur 3.2b). Drie van de acht soorten lieveheersbeestjes komen zowel in de Poelzone als in de bermen voor, zowel in oevers, heuvels als droge delen van bermen. Drie soorten komen alleen in de Poelzone voor (zowel in oevers als heuvels), maar deze komen sowieso maar in enkele monsters voor. Het Citroenlieveheersbeestje (Psyllobora vigintiduopunctata) eet bovendien uitsluitend meeldauw en geen bladluis. Het Aziatisch lieveheersbeestje (Harmonia axyridis) is één keer in een droge berm aangetroffen. Het Schaakbordlieveheersbeestje (Propylea quatuordecimpunctata) is een keer in een berm aangetroffen, maar uit de data was niet meer te achterhalen op welke locatie precies. 
Tabel 3.1c Aantal verzamelde monsters warin plaagsoorten zijn aangetroffen. Resultaten van individuele soorten bladluis, wantsen en uiltjes zijn weergegeven in tabel 3.1d.

\begin{tabular}{|c|c|c|c|c|c|c|c|c|c|c|c|c|}
\hline Plaagsoorten & Plaagbestrijders & B1 & B2 & B3 & B4 & Btot & P1 & P2 & P3 & P4 & Ptot & totaal \\
\hline Frankliniella occidentalis & roofmijt & & $4 b$ & $1 b$ & $1 b$ & 6 & 3ho & 3ho & 7ho & 2hoo & 15 & 21 \\
\hline Thrips fuscipennis & roofmijt & $1 b$ & & & & 1 & 5 ho & 20 & 10 & 10 & 9 & 10 \\
\hline bladluis ( 2 soorten) & $\begin{array}{l}\text { zweefvliegen } \\
\text { lieveheersbeestjes } \\
\text { galmuggen }\end{array}$ & 3 & 8 & 4 & 4 & 19 & 8 & 13 & 14 & 7 & 42 & 61 \\
\hline cycade & onbekend & $2 b$ & $1 b$ & & & 3 & & 1ho & 1ho & & 2 & 5 \\
\hline wants (7 soorten) & sluipwespen & & 3 & $2 b$ & & 5 & 4 & 6 & 2 & 4 & 16 & 21 \\
\hline $\begin{array}{l}\text { uiltjes - nachtvlinders ( } 2 \\
\text { soorten) }\end{array}$ & $\begin{array}{l}\text { sluipwespen, } \\
\text { roofwantsen }\end{array}$ & & 2 & & & 2 & 1 & & 1 & & 2 & 4 \\
\hline
\end{tabular}

Alle gevonden (groepen) plaagsoorten komen zowel in de Poelzone als in de bermen voor, zowel langs oevers als op heuvels en drogere delen van bermen (figuur 3.2c). Zowel trips-soorten, bladluizen als wantsen komen vaker in de Poelzone voor, maar daar zijn ook ruim twee keer zoveel monsters genomen (137) als in de bermen (62). Alleen Rozentrips (Thrips fuscipennis) en de groep wantsen lijkt daardoor ook relatief in meer monsters in de Poelzone aangetroffen te zijn dan in de bermen. De schade voor teeltgewassen van cycaden zijn onbekend.

Tabel 3.1d Aantal verzamelde monsters waarin plaagsoorten zijn aangetroffen. Resultaten van individuele soorten bladluis, wantsen en uiltjes.

\begin{tabular}{|c|c|c|c|c|c|c|c|c|c|c|c|}
\hline & B1 & B2 & B3 & B4 & Btot & P1 & P2 & P3 & P4 & Ptot & totaal \\
\hline \multicolumn{12}{|l|}{ Bladluizen } \\
\hline bladluissoorten & $3 b$ & 8 bo & $4 b$ & $3 b$ & 18 & 8 ho & $12 \mathrm{ho}$ & 14 ho & 7ho & 41 & 59 \\
\hline \multicolumn{12}{|l|}{ Wantsen } \\
\hline Dolycoris baccarum & & & & & & $1 z w$ & & & & 1 & 1 \\
\hline Lygocoris pabulinus & & & & & & 10 & & & & 1 & 1 \\
\hline Lygus maritimus & & 2 bo & & & 2 & & 10 & 10 & & 2 & 4 \\
\hline Lygus rugulipennis & & $1 b$ & $1 b$ & & 2 & 10 & 3ho & & & 4 & 6 \\
\hline Lygus sp. & & & & & & & & & $1 \mathrm{~h}$ & 1 & 1 \\
\hline Chrysodexis chalcites & & $1 z w$ & & & 1 & & & & & & 1 \\
\hline
\end{tabular}

$0=$ in oever

$\mathrm{h}=$ op heuvel (poelzone)

$\mathrm{b}=$ in berm

Als we het voorkomen van wantsen per soort bekijken, zijn er enkele soorten die alleen of vooral in de Poelzone (oevers en heuvels) zijn aangetroffen (figuur 3.2d). Het aantal monsters waarin individuele soorten zijn aangetroffen, is echter heel klein. Ook het aantal monsters op heuvels en droge delen van bermen waarin uiltjes zijn aangetroffen, is bijzonder laag. Van de bladluizen kon alleen de Aardappeltopluis (Macrosiphum euphorbiae) gedetermineerd worden en deze komt zowel in de Poelzone (oevers en heuvels) als in de bermen (oevers en droge delen) voor. Alle soorten die meer in de Poelzone voorkomen, konden niet verder worden gespecificeerd. 
Tabel 3.1e Aantal verzamelde monsters met tripsen en bladluizen die niet bekend staan als plaagsoort of waarvan dat niet bekend is.

\begin{tabular}{|c|c|c|c|c|c|c|c|c|c|c|c|}
\hline & B1 & B2 & B3 & B4 & Btot & P1 & P2 & P3 & P4 & Ptot & totaal \\
\hline \multicolumn{12}{|l|}{ Bladluizen } \\
\hline Aphis fabae & & & & & & & & 1ho & & 1 & 1 \\
\hline \multicolumn{12}{|l|}{ Tripsen } \\
\hline Thrips physapus & $5 b$ & 6 bo & $3 b$ & $4 b$ & 18 & 40 & 9ho & 5ho & 10 ho & 28 & 46 \\
\hline Thrips flavus & $1 b$ & & & & 1 & & 2ho & & & 2 & 3 \\
\hline Thrips vulgatissimus & & & $1 b$ & $2 b$ & 3 & & 10 & & & 1 & 4 \\
\hline Thrips major & & & & & & 7ho & 5 ho & 2ho & & 14 & 14 \\
\hline Thrips validus & $1 b$ & & $1 b$ & $1 b$ & 3 & 40 & $3 \mathrm{~h}$ & 2ho & 2ho & 11 & 14 \\
\hline Aelothripidae & & & & & & & $2 \mathrm{~h}$ & 2ho & 30 & 7 & 7 \\
\hline Chirothrips sp. & & & & & & & & & 10 & 1 & 1 \\
\hline Phlaeothripidae & & 5 bo & & & 5 & 2 ho & & $1 \mathrm{~h}$ & 2ho & 5 & 10 \\
\hline \multicolumn{12}{|l|}{$0=$ in oever } \\
\hline \multicolumn{12}{|l|}{$\mathrm{h}=$ op heuvel (poelzone) } \\
\hline $\mathrm{b}=$ in berm & & & & & & & & & & & \\
\hline
\end{tabular}

Er komen iets meer soorten neutrale herbivore soorten voor in de Poelzone (oevers en heuvels) dan in de bermen (oevers en droge bermen). Relatief gezien komen deze soorten niet in meer monsters voor in de Poelzone dan in de bermen (figuur 3.2e). De Zwarte bonenluis (Aphis fabae) is wel een plaag in boon, maar niet als plaagsoort geclassificeerd omdat dit gewas niet of weinig voorkomt in de omgeving. In de Poelzone komt een aantal van deze tripsen vaker voor, maar veel soorten konden niet op soortniveau worden gedetermineerd. Een aantal soorten is alleen in de Poelzone aangetroffen: Thrips major, Odontothrips, Aelothripidae en Chirothrips sp.. Het aantal monsters met deze soorten is echter klein. Frankliniella intonsa wordt in sommige studies als plaag van aardbei genoemd, maar de daadwerkelijke schade die ze in aardbei of andere gewassen kunnen geven, is niet bekend.

Tabel 3.2 Percentage van het totaalaantal verzamelde individuen van trips-soorten t.o.v. het totaalaantal verzamelde individuen van alle soorten gezamenlijk (10.886 individuen).

\begin{tabular}{|c|c|c|c|}
\hline & $\%$ aantal & $\%$ in bermen & $\%$ in Poelzone \\
\hline \multicolumn{4}{|l|}{ Plaagsoorten } \\
\hline Frankliniella occidentalis & 2.2 & 1.16 & 1.02 \\
\hline Thrips tabaci & 13.1 & 8.63 & 4.43 \\
\hline totaal & 15.5 & 9.8 & 5.7 \\
\hline Thrips physapus & 36.5 & 29.66 & 6.86 \\
\hline Chirothrips manicatus & 0.0 & 0.01 & 0.01 \\
\hline Thrips flavus & 0.1 & 0.01 & 0.06 \\
\hline Thrips vulgatissimus & 0.1 & 0.06 & 0.02 \\
\hline Thrips sp. & 35.3 & 17.18 & 18.08 \\
\hline Odonto sp. & 0.1 & 0.00 & 0.09 \\
\hline Chirothrips sp. & 0.2 & 0.00 & 0.20 \\
\hline Phalaeothripidae & 0.0 & 0.00 & 0.01 \\
\hline totaal & 85.5 & 52.8 & 31.7 \\
\hline
\end{tabular}


* Frankliniella occidentalis

- Thrips fuscipennis

= Thrips tabaci

" Thrips physapus

- Chirothrips manicatus

- Thrips flavus

- Thrips vulgatissimus

- Thrips major

- Thrips validus

- Frankliniella intonsa

- Thrips spec

- Odonto spec

- Aelothripidae

- Chirothrips spec

" Phlaeothripidae

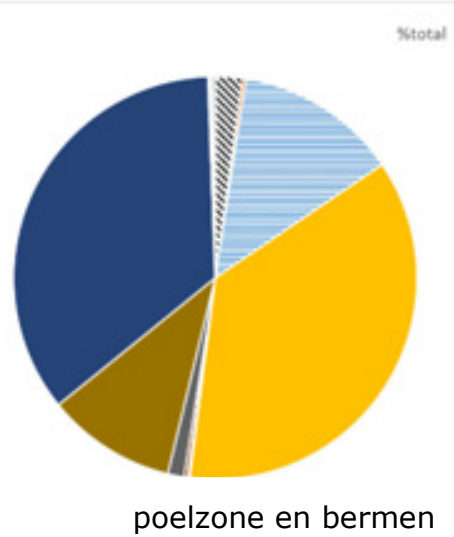

Figuur 3.2 Percentage van totaalaantal gevonden tripsen van plaagtripsen (Frankliniella occidentalis zwart schuine streep, Thrips fuscipennis niet zichtbaar en Thrips tabaci blauwe rechte streep) t.o.v. neutrale tripsen.

Het aandeel van individuen plaagsoorten van alle aangetroffen individuen trips in bermen en Poelzone tezamen is $15,5 \%$, het aandeel van individuen neutrale soorten is $84,5 \%$ (tabel 3.2 , figuur 3.2 ). Plaagsoorten maken dus maar een klein deel uit van de totale gemonsterde populatie tripsen, zowel in bermen als in de Poelzone.

De aantallen individuen van tripsen zijn hoger in de bermen dan in de Poelzone, zowel voor de drie plaagtripsen $(9,8 \%$ vs. $5,7 \%)$ als voor de neutrale soorten ( $52,8 \%$ vs. $31,7 \%)$ (tabel 3.2 , figuur 3.3 ). Dit wordt voornamelijk veroorzaakt door de neutrale herbivore soort Thrips physapus en door de plaagsoort Tabakstrips (Thrips tabaci), die beide vaker gevonden zijn in de bermen. Voor de overige soorten trips is het verschil in aantallen tussen berm en Poelzone klein. In totaal is in de bermen $63 \%$ van het totaal aantal individuen trips gevonden, tegenover $37 \%$ in de Poelzone, ondanks het hogere aantal monsters dat verzameld is in de Poelzone.

\& Frankliniella occidentalis

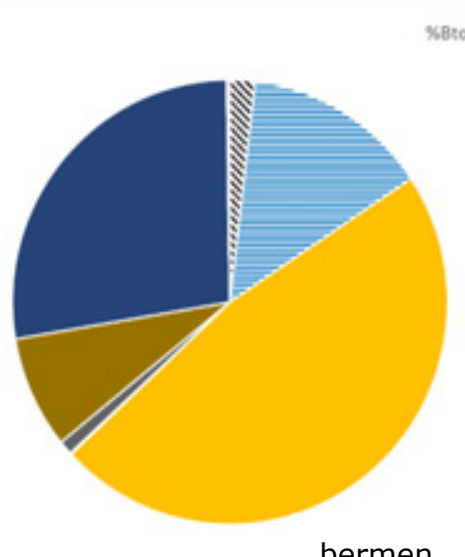

serot

- Thrips fuscipennis

$\equiv$ Thrips tabaci

= Thrips physapus

- Chirothrips manicatus

- Thrips flavus

- Thrips vulgatissimus

- Thrips major

- Thrips validus

- Frankliniella intonsa

- Thrips spec

- Odonto spec

- Aelothripidae

- Chirothrips spec

" Phlaeothripidae

bermen

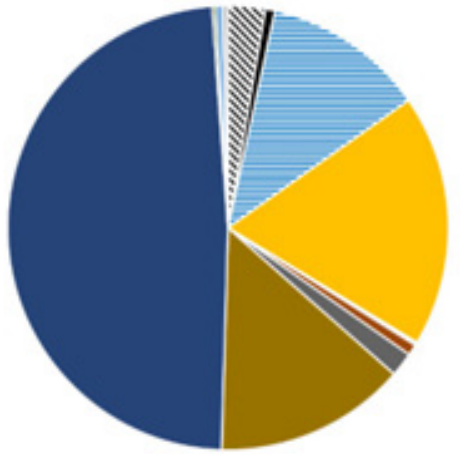

poelzone

Figuur 3.3 Percentage van totaalaantal gevonden tripsen van plaagtripsen in bermen (links) en in de Poelzone (rechts) t.o.v. neutrale tripsen. Frankliniella occidentalis zwart schuine streep, Thrips fuscipennis niet zichtbaar/zwart en Thrips tabaci blauwe rechte streep zijn plaagtripsen. 


\subsection{Voorkomen waardplanten in Poelzone en bermen}

Tabel 3.3 Belangrijkste waardplanten (op basis van aantal monsters) van natuurlijke vijanden en plaaginsecten en de locaties waar ze aangetroffen zijn in de vegetatieopnames.

\begin{tabular}{|c|c|c|c|c|c|}
\hline Natuurlijke vijanden & $\begin{array}{l}\text { Waardplant } \\
\text { top } 3\end{array}$ & $\begin{array}{l}\text { Andere } \\
\text { waard- } \\
\text { planten }\end{array}$ & Plaaginsecten & $\begin{array}{l}\text { Waardplant } \\
\text { top } 3\end{array}$ & $\begin{array}{l}\text { Andere } \\
\text { waard- } \\
\text { planten }\end{array}$ \\
\hline $\begin{array}{l}\text { Praon volucre } \\
\text { (sluipwesp) }\end{array}$ & Riet (obs) & 0 & Thrips tabaci & $\begin{array}{l}\text { Herfstleeuwentand } \\
\text { Grote zandkool } \\
\text { Jacobskruiskruid }\end{array}$ & 29 \\
\hline $\begin{array}{l}\text { Phytoseideae } \\
\text { (roofmijten) }\end{array}$ & $\begin{array}{l}\text { Rode klaver } \\
\text { Heelblaadjes } \\
\text { Herfstleeuwentand }\end{array}$ & 9 & cycade & $\frac{\text { Paardenbloem }}{\frac{\text { Hondsdraf }}{\text { Madelief }}}$ & \\
\hline lieveheersbeestje & $\begin{array}{l}\text { vangnetmonster } \\
\text { Akkerdistel } \\
\text { Krulzuring } \\
\text { Paardenbloem } \\
\text { Reukeloze kamille }\end{array}$ & 0 & $\begin{array}{l}\text { wants } \\
\text { (7 soorten) }\end{array}$ & vangnetmonster & 0 \\
\hline $\begin{array}{l}\text { zweefvlieg } \\
\text { (12 soorten) }\end{array}$ & $\begin{array}{l}\text { vangnetmonster } \\
\text { Riet } \\
\text { Herfstleeuwentand } \\
\text { Paardenbloem } \\
\text { Rode klaver } \\
\end{array}$ & 0 & & & \\
\hline $\begin{array}{l}\text { gaasvlieg } \\
\text { ( } 2 \text { soorten) }\end{array}$ & $\begin{array}{l}\text { vangnetmonster } \\
\text { Fluitenkruid } \\
\text { Gewone berenklauw } \\
\text { Herfstleeuwentand } \\
\text { Paardenbloem }\end{array}$ & 0 & & & \\
\hline
\end{tabular}

Herfstleeuwentand, Jacobskruiskruid, Paardenbloem, Rode klaver, Krulzuring en Hondsdraf bevatten zowel plaaginsecten (bladluis, trips) als hun natuurlijke vijanden (Orius niger, lieveheersbeestjes). Vooral Orius niger komt voor op veel verschillende soorten planten, maar ook zijn prooien: plaagtripsen Frankliniella occidentalis (Californische trips) en Thrips tabaci (Tabakstrips) komen op erg veel soorten waardplanten voor. Omdat de meeste waardplanten slechts één of enkele malen bemonsterd zijn, kunnen we niet echt van de belangrijkste waardplanten spreken, maar tabel 3.3 geeft wel inzicht in het feit dat sommige insecten op een beperkt aantal waardplanten voorkomen, terwijl andere op veel verschillende soorten waardplanten voorkomen. Zweefvliegen komen niet op erg veel soorten waardplanten voor, maar bladluizen wel. Zweefvliegen komen het vaakst voor in vangnetmonsters, wantsen en uiltjes zijn zelfs alleen in vangnetmonsters gevonden. Dit zijn snelle vliegers die bij het bemonsteren van bloemen snel wegvliegen. 
Tabel 3.4 Locaties, hoeveelheden en periodes van waardplanten van natuurlijke vijanden en plaaginsecten (op basis van aantal monsters; een compleet overzicht van de aangetroffen plantensoorten is te vinden in bijlage 2). Abundantie: $x=\operatorname{sporadisch/zeldzaam}(s, r), x x=$ regelmatig voorkomend $(0, I f, f, l a), x x x=$ veel tot dominant $(a, d) . B 1-B 4 / P 1-P 4$ : soort is in alle locaties in bermen/Poelzone gevonden.

\begin{tabular}{|c|c|c|c|c|c|c|}
\hline Waardplant & Berm & $\begin{array}{l}\max \\
\text { abund }\end{array}$ & Periode & Poelzone & $\begin{array}{l}\max \\
\text { abund }\end{array}$ & Periode \\
\hline Herfstleeuwentand & $\mathrm{B} 1-\mathrm{B} 4$ & $x x$ & (juni), aug & $\mathrm{P} 1, \mathrm{P} 4$ & $\mathrm{x}$ & aug \\
\hline Wilde cichorei & $\mathrm{B} 2$ & $x$ & aug & $\mathrm{P} 1, \mathrm{P} 2$ & $x x$ & aug \\
\hline Scherpe boterbloem & $\mathrm{B} 2, \mathrm{~B} 3, \mathrm{~B} 4$ & $x x$ & april, juni, aug & $\mathrm{P} 1$ - P4 & $x x$ & april, juni, aug \\
\hline Rode klaver & $\mathrm{B} 1-\mathrm{B} 4$ & $x x x$ & april, juni, aug & $\mathrm{P} 1-\mathrm{P} 4$ & $x x x$ & april, juni, aug \\
\hline Grote zandkool & B3 & $x$ & aug & & & \\
\hline Echte valeriaan & B2 & $x x x$ & juni & & & \\
\hline Krulzuring & $\mathrm{B} 1-\mathrm{B} 4$ & $x x$ & april, juni, aug & $\mathrm{P} 1$ - P4 & $x x$ & juni, aug \\
\hline Riet & $\mathrm{B} 1, \mathrm{~B} 2$ & $x x x$ & april, juni, aug & $\mathrm{P} 1-\mathrm{P} 4$ & $x x x$ & april, juni, aug \\
\hline Duizendblad & $\mathrm{B} 1-\mathrm{B} 4$ & $x x x$ & april, juni, aug & $\mathrm{P} 1$ - P4 & $x x x$ & april, juni, aug \\
\hline Reukeloze kamille & B2 & $x x$ & juni, aug & $\mathrm{P} 1, \mathrm{P} 2, \mathrm{P} 3$ & $x x$ & juni, aug \\
\hline Heelblaadjes & & & & $\mathrm{P} 1$ - P4 & $x x x$ & april, (juni, aug) \\
\hline Paardenbloem & $\mathrm{B} 1-\mathrm{B} 4$ & $x x x$ & april, juni, aug & $\mathrm{P} 1, \mathrm{P} 4$ & $x x x$ & april, juni \\
\hline Fluitenkruid & $\mathrm{B} 1-\mathrm{B} 4$ & $x x$ & april, juni, aug & P1, P3, P4 & $x x$ & april, juni \\
\hline Gewone berenklauw & $\mathrm{B} 1-\mathrm{B} 4$ & $x x$ & april, juni, aug & & & \\
\hline Knoopkruid & & & & $\mathrm{P} 1$ - P4 & $x x x$ & april, juni, aug \\
\hline Vogelwikke & B1, B4 & $x x x$ & juni, aug & $P 1-P 4$ & $x x$ & juni, aug \\
\hline
\end{tabular}


Tabel 3.5 Typische oeverplanten en daarop aangetroffen naturlijke vijanden en plaaginsecten.

\begin{tabular}{|c|c|c|c|c|c|c|}
\hline Oeverplant & $\begin{array}{l}\text { Plaag } \\
\text { soort }\end{array}$ & $\begin{array}{l}\text { Aantal } \\
\text { monsters }\end{array}$ & $\begin{array}{l}\text { Neutrale } \\
\text { herbivoor }\end{array}$ & $\begin{array}{l}\text { Aantal } \\
\text { monsters }\end{array}$ & Bestrijder & $\begin{array}{l}\text { Aantal } \\
\text { monsters }\end{array}$ \\
\hline Dotterbloem & & & Frankliniella intonsa & 1 & Orius niger & 1 \\
\hline Echte valeriaan & Thrips tabaci & 1 & Thrips sp. & 1 & & \\
\hline Gele lis & & & Thrips sp. & 1 & & \\
\hline \multirow[t]{2}{*}{ Grote wederik } & bladluis & 1 & Frankliniella intonsa & 1 & Phytoseideae & 1 \\
\hline & & & Thrips sp. & 1 & & \\
\hline \multirow{3}{*}{$\begin{array}{l}\text { Harig } \\
\text { wilgenroosje }\end{array}$} & bladluis & 1 & Thrips physapus & 1 & Orius niger & 3 \\
\hline & $\begin{array}{l}\text { Thrips } \\
\text { fuscipenis }\end{array}$ & 4 & Frankliniella intonsa & 5 & & \\
\hline & Thrips tabaci & 2 & Thrips sp. & 3 & & \\
\hline \multirow[t]{5}{*}{ Heelblaadjes } & bladluis & 2 & Thrips physapus & 4 & Orius niger & 3 \\
\hline & $\begin{array}{l}\text { Frankliniella } \\
\text { occidentalis }\end{array}$ & 1 & Thrips major & 1 & Phytoseideae & 3 \\
\hline & Thrips tabaci & 4 & Frankliniella intonsa & 4 & & \\
\hline & & & Thrips sp. & 6 & & \\
\hline & & & Chirothrips sp. & 1 & & \\
\hline Riet & & & & & zweefvlieg & 2 \\
\hline \multirow[t]{2}{*}{ Watermunt } & Thrips tabaci & 1 & Frankliniella intonsa & 1 & Orius niger & 2 \\
\hline & & & Thrips sp. & 1 & Phytoseideae & 2 \\
\hline
\end{tabular}

Er zijn weinig waardplanten die zich beperken tot de berm, alleen Grote zandkool en Echte valeriaan (tabel 3.4). Het is aannemelijk dat deze soorten buiten de gemonsterde plekken in de Poelzone kunnen voorkomen. Heelblaadjes en Knoopkruid komen alleen voor in de Poelzone en zijn wat meer gebonden aan natuurlijk beheer.

Een aantal vroegbloeiers als Dotterbloem en Gele lis komt alleen langs de oevers in de Poelzone voor. Laatbloeiers als Herfstleeuwentand en Wilde cichorei komen zowel in de Poelzone als in de bermen voor, maar veel planten bloeien een groot deel van het seizoen.

Er zijn weinig plantensoorten die zich beperken tot oevers, de meeste (algemene) soorten komen zowel langs oevers voor als op heuvels in de Poelzone en langs oevers en drogere delen van regulier beheerde bermen. Riet komt alleen langs oevers voor en Valeriaan en Heelblaadjes komen alleen langs oevers van de Poelzone voor. Om te bepalen of waardplanten in oevers een meer afwijkende populatie plaag(bestrijdende) insecten bevatten dan waardplanten elders in de Poelzone of in de bermen, nemen we waardplanten apart die kenmerkend zijn voor oevervegetaties, ongeacht of er veel insectensoorten op zijn aangetroffen. Er zijn 35 soorten waargenomen die kenmerkend zijn voor oevers, 9 soorten daarvan zijn bemonsterd op insecten.

Het blijkt dat de oeverplanten zowel plaagsoorten, neutrale herbivore soorten als plaagbestrijders bevatten (tabel 3.5). Er zijn wel soorten gevonden zonder plaagbestrijders (Echte valeriaan, Gele lis) en soorten zonder plaagsoorten (Dotterbloem, Gele lis, Riet), maar dat kan veroorzaakt zijn door het kleine aantal monsters. 


\subsection{Perioden van voorkomen plaagbestrijdende en plaagsoorten}

Tabel 3.6 Seizoenseffecten bij trips en bijbehorende natuurlijke vijanden (aantal monsters).

\begin{tabular}{|c|c|c|c|c|c|}
\hline Natuurlijke vijanden & april & mei & juni & juli & augustus \\
\hline Orius niger & 3 & 5 & 14 & 30 & 20 \\
\hline \multicolumn{6}{|c|}{ Trips plaag } \\
\hline Frankliniella occidentalis & 1 & 1 & 3 & 9 & 7 \\
\hline Thrips fuscipennis & & 1 & 2 & 6 & 1 \\
\hline Thrips tabaci & 2 & 9 & 16 & 17 & 19 \\
\hline \multicolumn{6}{|c|}{ Trips neutraal } \\
\hline Thrips physapus & 2 & 6 & 12 & 13 & 13 \\
\hline Chirothrips manicatus & & & & 1 & \\
\hline Thrips flavus & & & 3 & & \\
\hline Thrips vulgatissimus & & 1 & & 2 & 1 \\
\hline Thrips major & & 5 & 4 & 2 & 3 \\
\hline Thrips validus & 2 & 3 & 2 & 2 & 5 \\
\hline Frankliniella intonsa & 9 & 13 & 11 & 20 & 19 \\
\hline Thrips sp. & 8 & 41 & 35 & 33 & 33 \\
\hline Odontothrips sp. & & & & 1 & 1 \\
\hline
\end{tabular}

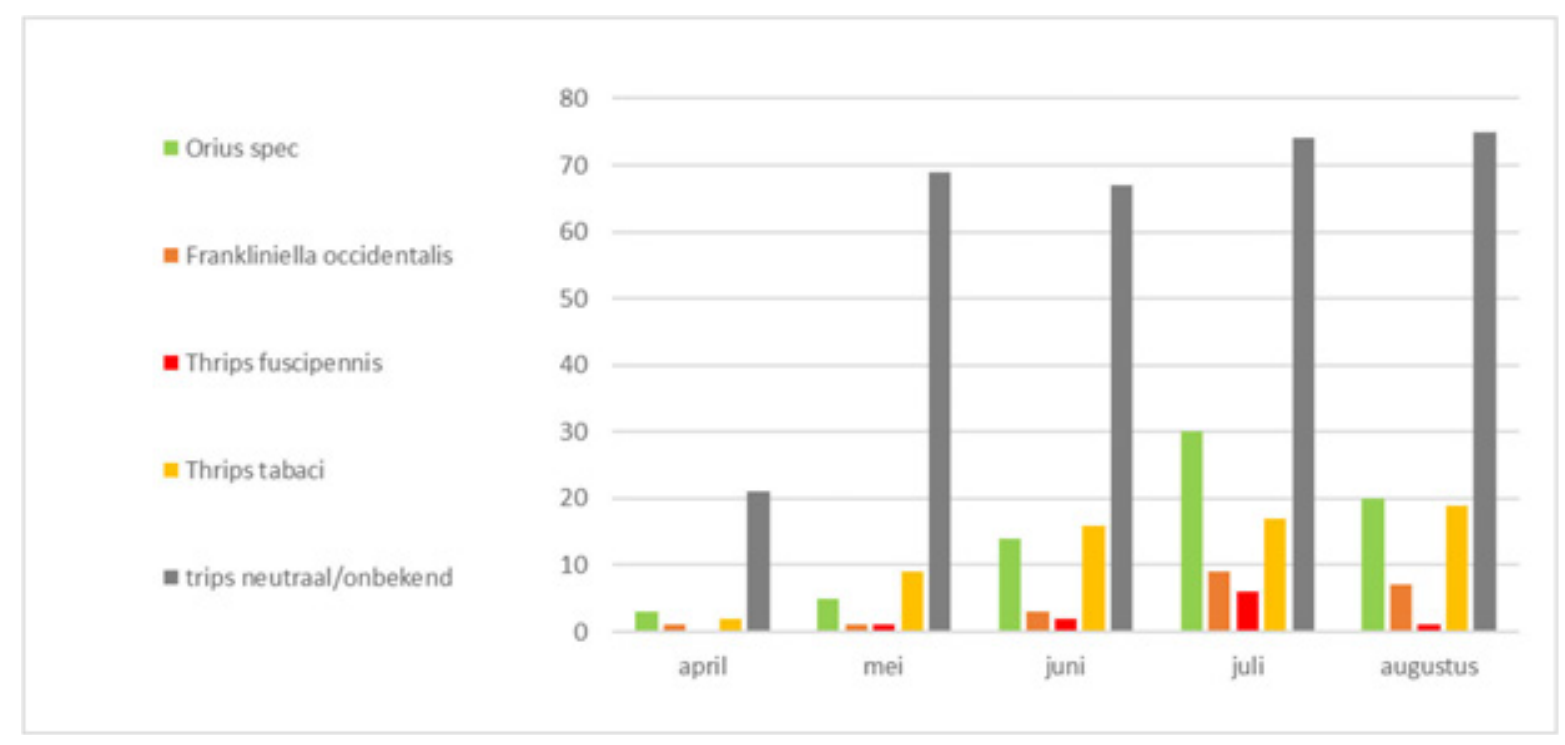

Figuur 3.4 Seizoenseffecten bij trips en bijbehorende natuurlijke vijanden (aantal monsters).

Gedurende het seizoen neemt zowel het aantal verzamelde monsters Orius niger (natuurlijke vijand van trips) als het aantal monsters met tripsen toe. Zowel Orius als tripsen hebben hun maximale aantallen monsters in juli. Alleen de groep neutrale tripsen neemt al toe in mei en neemt nog niet af in augustus. 
Tabel 3.7 Seizoenseffecten bij bladluis en bijbehorende natuurlijke vijanden (op basis van aantallen monsters).

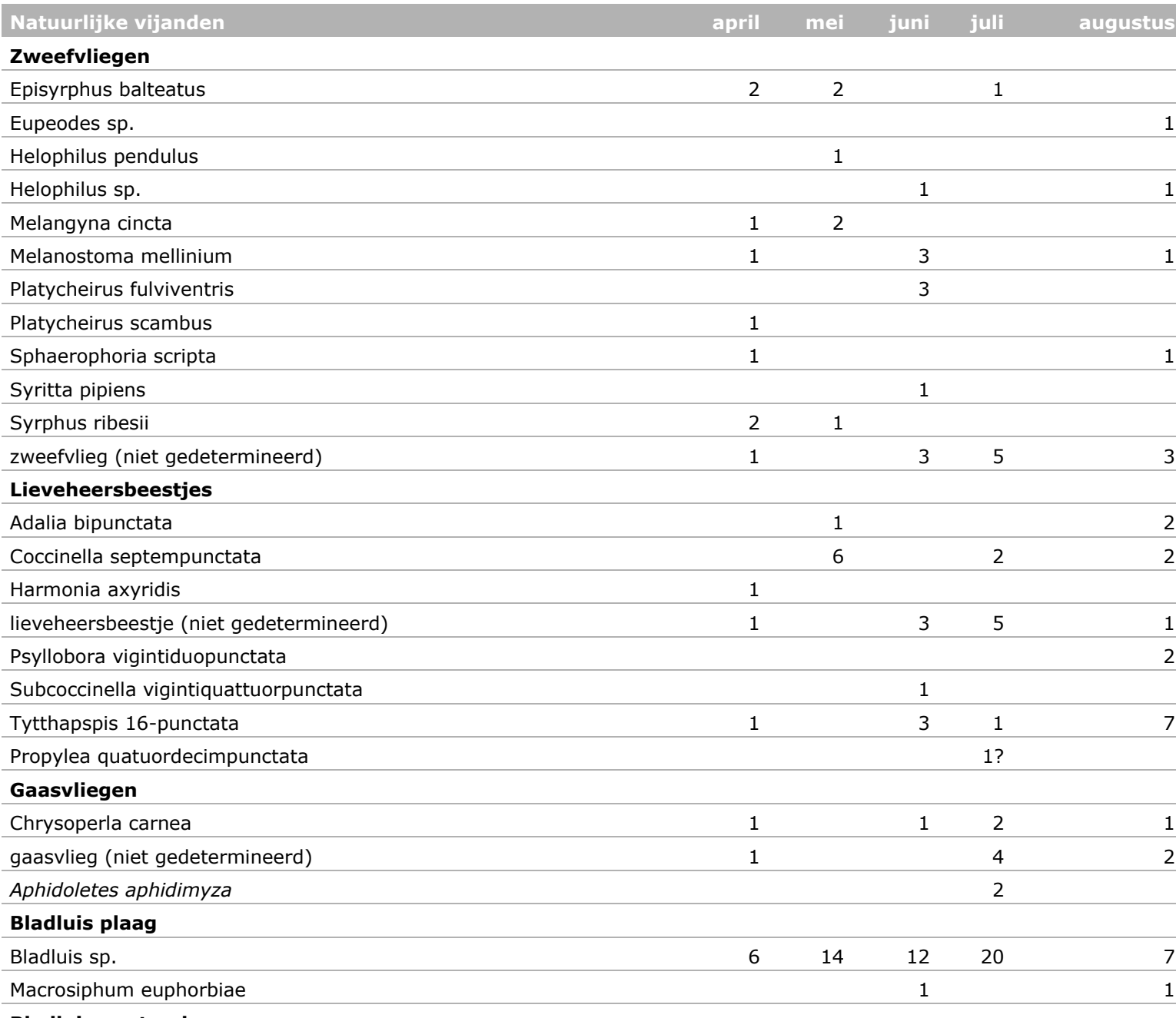

\section{Bladluis neutraal}

Hyalopterus pruni

2

Aphis fabae

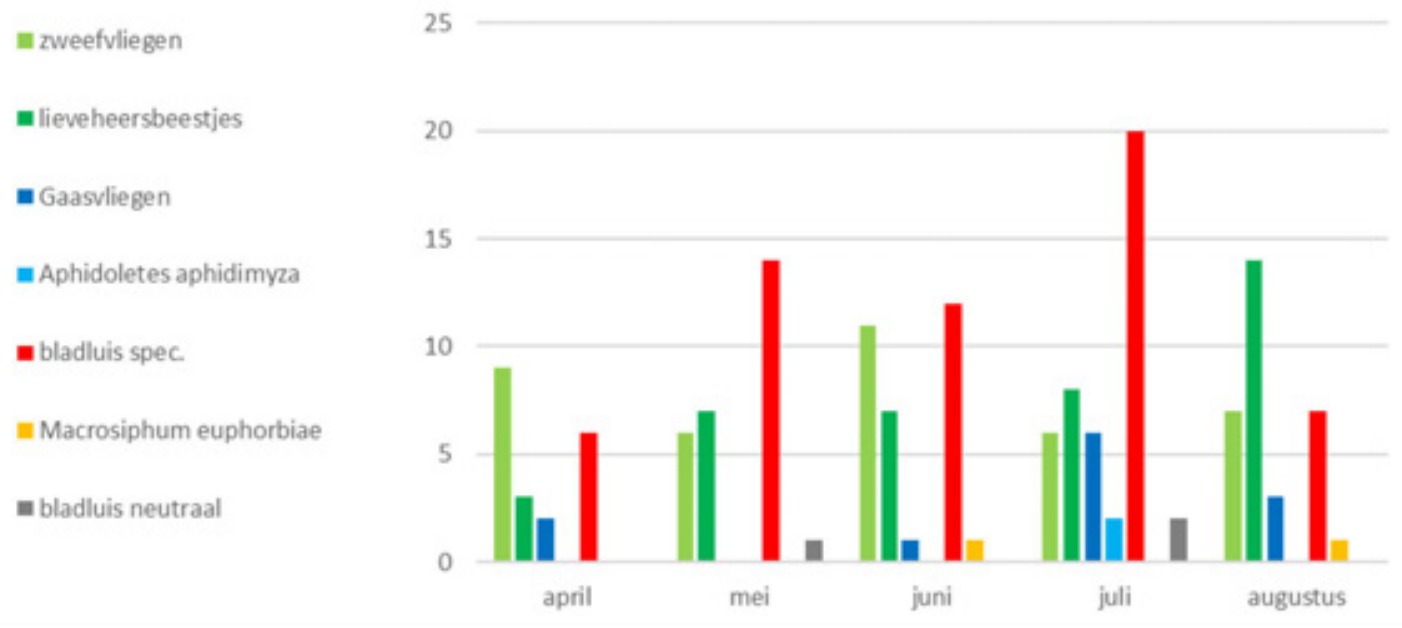

Figuur 3.5 Seizoenseffecten bij bladluis en bijbehorende naturlijke vijanden (op basis van aantallen monsters). 
De ongedefinieerde groep bladluizen heeft zijn maximale aantal in juli. Sommige natuurlijke vijanden hebben hun maximale aantal in juni, juli of in augustus.

\subsection{Aanvullende waarnemingen}

In de poelzone zijn opvallend veel bladluisplaagbestrijders gevonden, zoals lieveheersbeestjes, gaasvliegen, zweefvliegen, sluipwespen, soldaatjes en galmuggen. Deze kunnen nuttig zijn als ze migreren van de berm naar kassen en daar een bijdrage leveren aan de bestrijding van bladluis. Deze plaagbestrijders hebben in de berm bladluis nodig om zich te kunnen vermeerderen. Er werd opvallend veel bladluis gevonden op distel (Zwarte bonenluis, Aphis fabae) en bijna altijd in aanwezigheid van natuurlijke vijanden van bladluis (figuur 3.3 en 3.4). Deze bladluizen vormen geen bedreiging voor de glastuinbouwgewassen, met uitzondering van boon, en fungeren op die manier als een 'bankersysteem', een voedselvoorraad, voor natuurlijke vijanden van bladluis. Een verwante bladluis Aphis rumicis is aangetroffen op krulzuring met bladluisplaagbestrijders (figuur 3.5). Verder werden grote hoeveelheden bladluis gevonden op riet. Dit bleek te gaan om de Melige pruimenluis, Hyalopterus pruni (figuur 3.6). Ook deze soort is niet schadelijk voor glastuinbouwgewassen, maar blijkt een enorme voedingsbron te zijn voor allerlei bladluisplaagbestrijders.

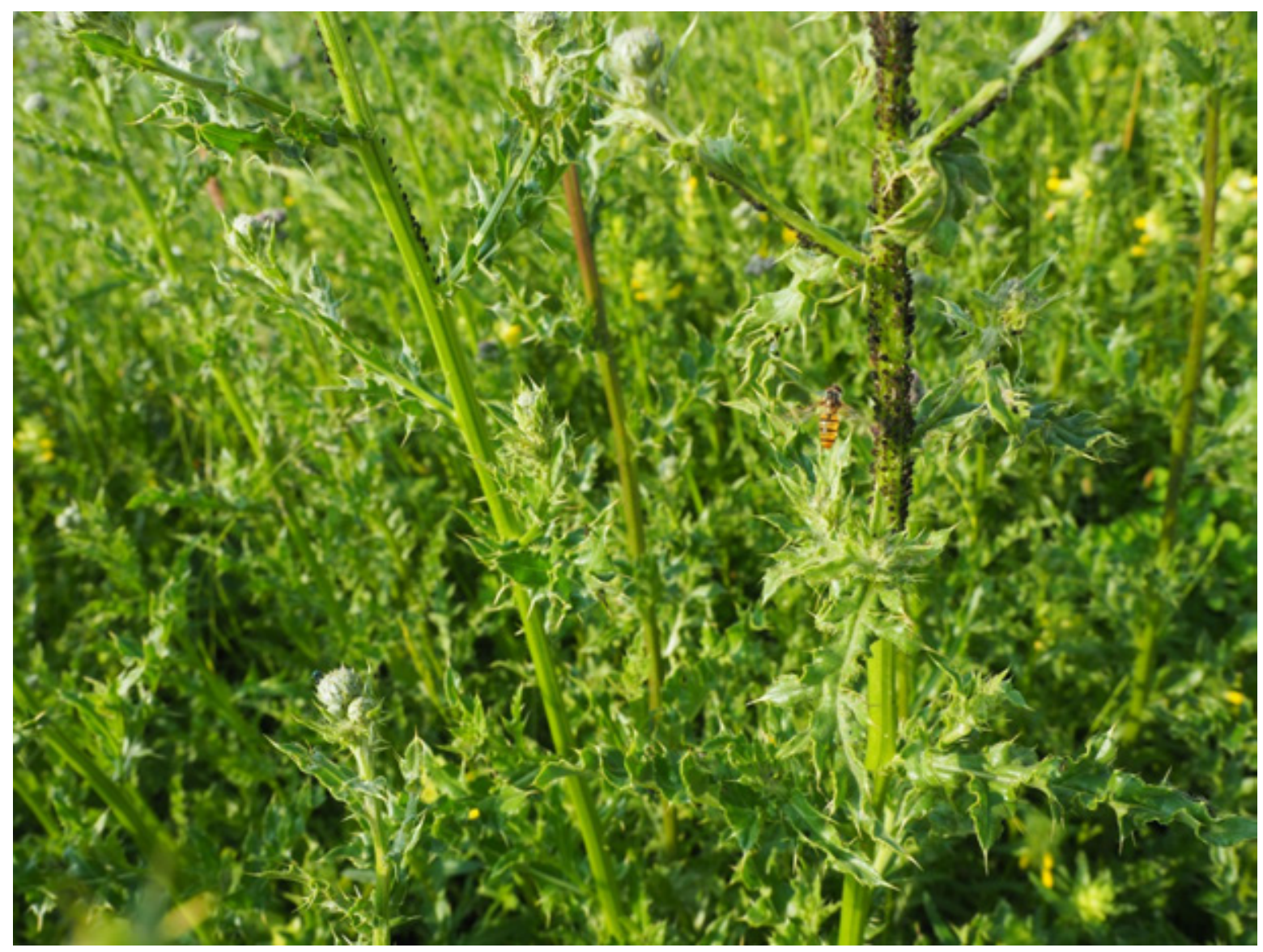

Figuur 3.6 Akkerdistel met Zwarte bonenluis (Aphis fabae cirsiiacanthoidis) en Episyrphus balteatus (Pyamazweefvlieg). 


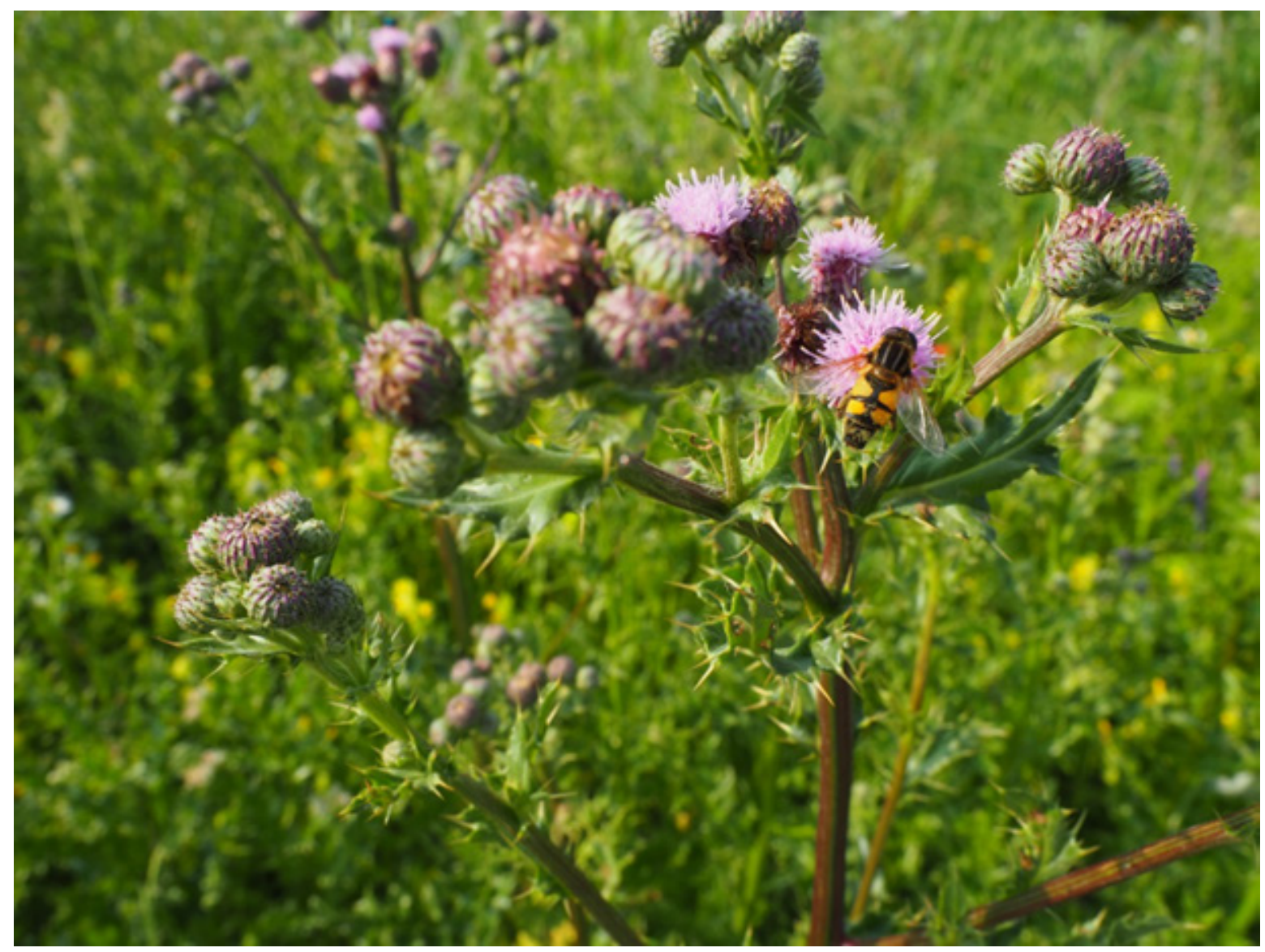

Figuur 3.7 Akkerdistel met de Moeraspendelvlieg (Helophilus hybridus).

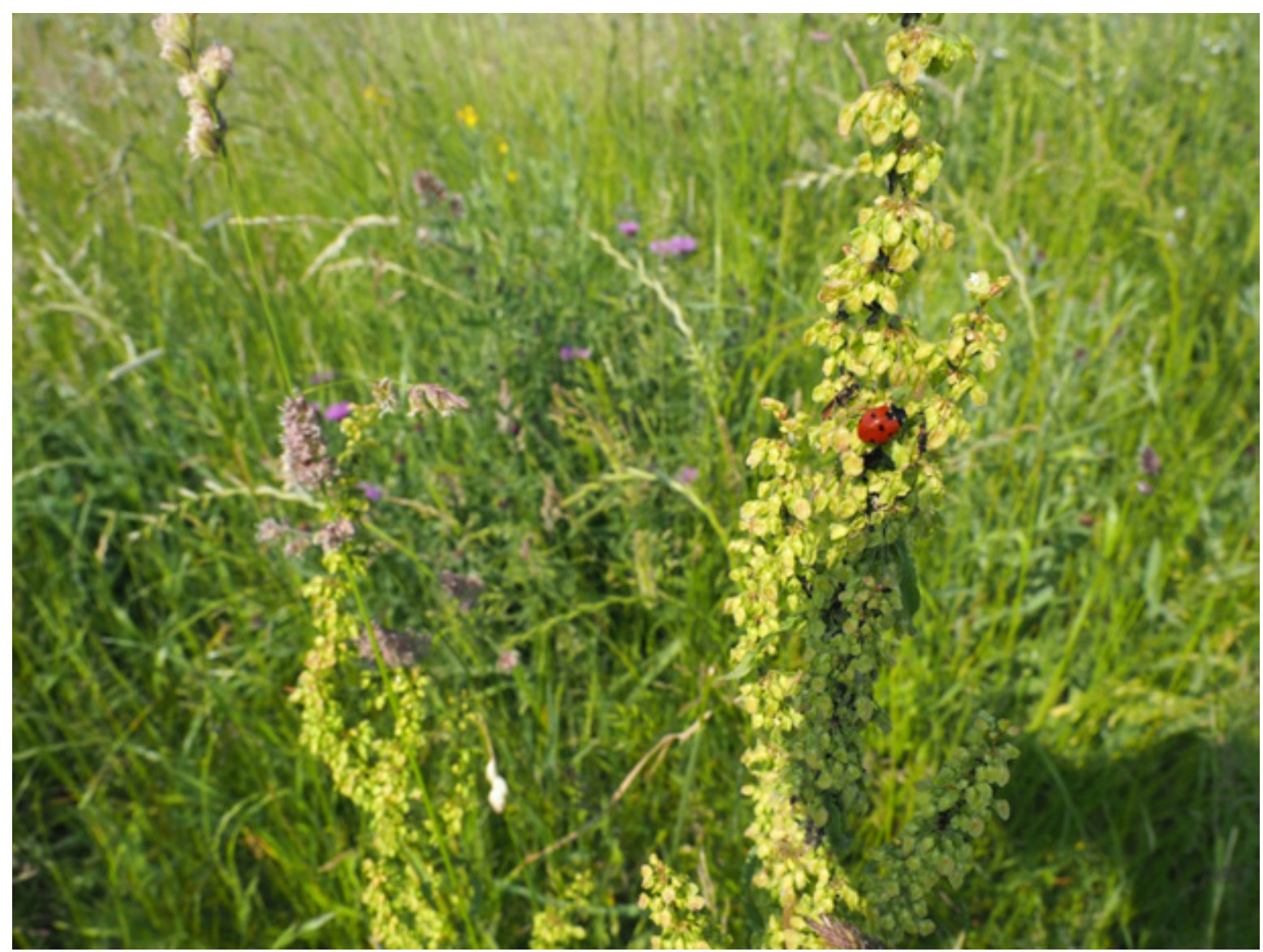

Figuur 3.8 Krulzuring met Aphis rumicis en het zevenstippelige lieveheersbeestje (Coccinella septempunctata). 


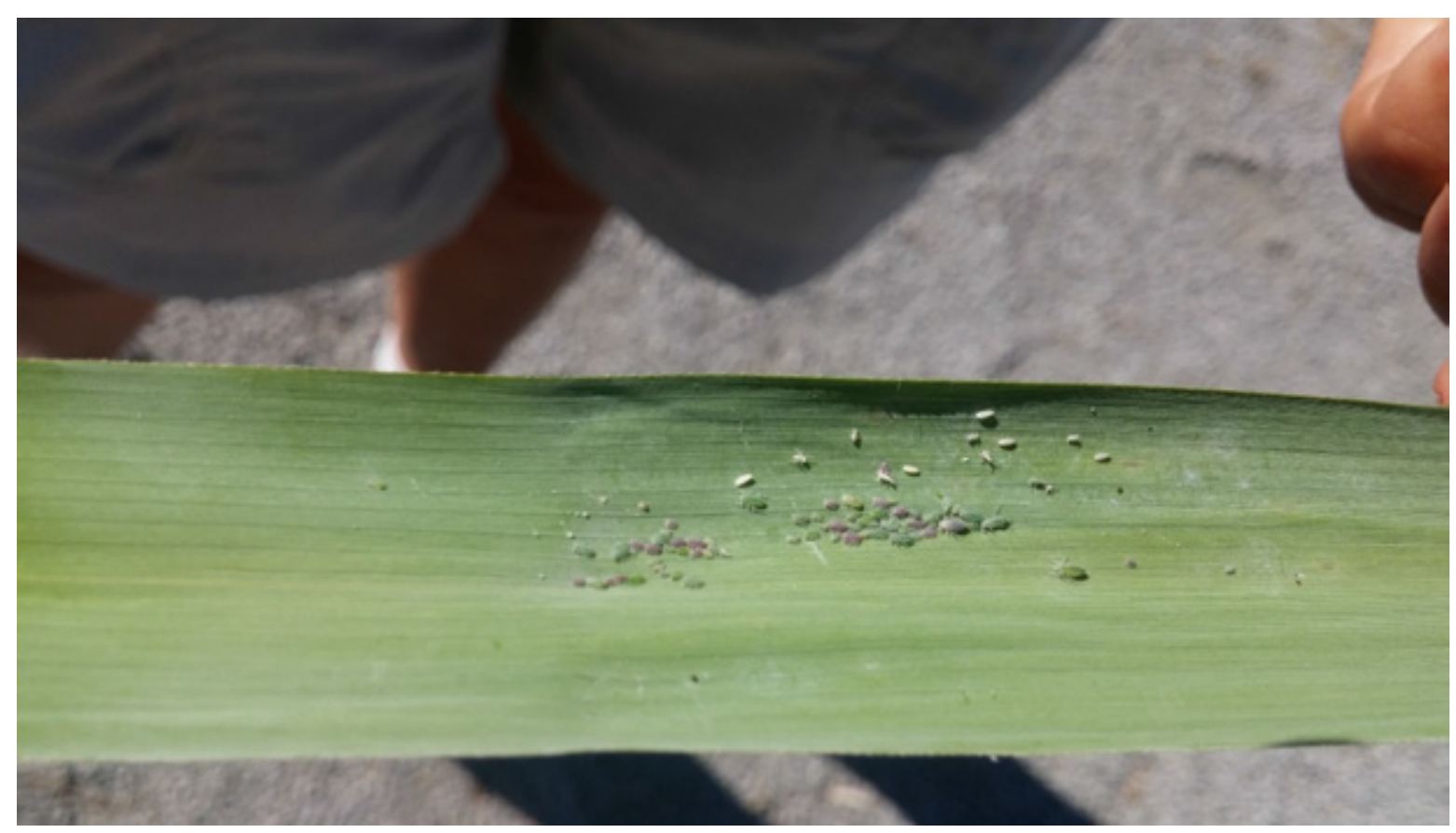

Figuur 3.9 De Melige pruimenluis (Hyalopterus pruni) op riet met eieren van zweefvliegen.

\subsection{Perioden van voorkomen plaaginsecten in Poelzone, bermen en kassen}

Van een van de tuinders is een enquêteformulier ontvangen met waargenomen plagen en gebruikte methoden van plaagbestrijding. Aangezien aan de hand van waarnemingen uit één kas geen betrouwbare uitspraken gedaan kunnen worden, hebben we dit onderdeel van het onderzoek niet kunnen opnemen in deze rapportage. 


\section{Conclusies, discussie en aanbevelingen}

\subsection{Conclusies}

\section{Vergelijken type en hoeveelheid groen binnen $1 \mathbf{~ k m}$ van elke locatie}

Het groen in de omgeving en dus mogelijk leefgebied voor waardplanten en insecten is voor de locaties P3 en P4 iets afwijkend van de andere onderzochte locaties in de Poelzone (P1 en P2), de regulier beheerde bermen langs de Julianaweg (B1 en B2) en langs de provinciale weg (B3 en B4). De gevonden soorten insecten lijken in P3 en P4 echter niet duidelijk af te wijken van die in P1 en P2. Ook is er weinig verschil tussen de hoeveelheid groen in de omgeving tussen oevers en droge delen binnen één locatie, maar deze liggen ook tegen elkaar aan, zodat de omgeving vrijwel gelijk is.

Alleen de roofkever Cantharis livida komt alleen voor in P3 en P4 en niet in andere locaties. Ook de roofwants Nabis sp. komt in de Poelzone alleen in P3 en P4 voor. De plaagsoort Behaarde wants (Lygus rugulipennis) komt in de Poelzone alleen in P1 en P2 voor. Het totaalaantal monsters van deze soorten is echter zo laag dat dit op toeval kan berusten. Het wat afwijkende type groen in de omgeving van P3 en P4 lijkt dus geen grote invloed te hebben op de soortensamenstelling van insecten in het onderzochte gebied.

\section{Bepalen belangrijkste soorten plaaginsecten en plaagbestrijders in Poelzone en bermen} Er komen heel veel verschillende soorten natuurlijke plaagbestrijders, plaagsoorten, neutrale herbivore soorten voor in onderzochte locaties in de regulier beheerde bermen en in de Poelzone. Er komen iets meer soorten plaagbestrijders, plaagsoorten en neutrale herbivore soorten voor in de Poelzone dan in de bermen. In de Poelzone komen meer plantensoorten voor en daarom zijn hier meer monsters genomen. Als we hiervoor corrigeren, komt de natuurlijke vijand Orius niger relatief gezien in meer monsters voor in de Poelzone dan in de bermen, evenals de Rozentrips Thrips fuscipennis en wantsen. Orius niger is een belangrijke bestrijder van tripsen. Deze tripsen zijn een belangrijke voedselbron voor Orius niger.

De meeste natuurlijke vijanden komen zowel in locaties langs oevers als in droge delen van de Poelzone en bermen voor. Een paar natuurlijke vijanden, evenals enkele plaagsoorten en neutrale herbivore soorten, zijn alleen in oevers langs de Poelzone gevonden, maar deze zijn alle slechts in enkele monsters aangetroffen. Ook zijn er enkele soorten die alleen in drogere delen zijn aangetroffen.

Opvallend is dat de aantallen individuen tripsen hoger zijn in de locaties in bermen vergeleken met die in de Poelzone; dat komt vooral door de hogere aantallen van de neutrale herbivoor Thrips physapus en de plaagsoort Tabakstrips (Thrips tabaci) in bermen. Het aandeel plaagtripsen is echter veel lager dan dat van neutrale soorten, zowel in de Poelzone als in de bermen. De hogere aantallen tripsen in regulier beheerde bermen kan te maken hebben met het feit dat de belangrijkste vijand van trips, Orius niger, hier in minder monsters is aangetroffen.

\section{Bepalen belangrijkste waardplanten plaagbestrijders en plaaginsecten in Poelzone en bermen}

De gevonden (waard)planten in de locaties in bermen en in de Poelzone komen voor een deel overeen: er zijn 69 plantensoorten, vaak de wat algemenere soorten, die zowel voorkomen in de onderzochte locaties in bermen als in de Poelzone (bijlage 2). Er zijn 71 plantensoorten die alleen in onderzochte locaties in de Poelzone voorkomen, maar ook 27 plantensoorten die alleen in de locaties in bermen voorkomen. De plantenpopulaties vullen elkaar dus aan als het gaat om aanbod van waardplanten.

Zowel plaagbestrijders als plaagsoorten komen op algemene soorten voor als Jacobskruiskruid, Paardenbloem, (Scherpe en Kruipende) boterbloem, Hondsdraf en Madelief. Ze komen veel voor op 
wat later bloeiende algemene soorten als Herfstleeuwentand en Jacobskruiskruid, maar ook op de vroegbloeiers als Dotterbloem en Gele lis, die alleen langs oevers in de Poelzone voorkomen. Deze vroege oeversoorten zijn belangrijk voor het jaarrond aanbod van voedsel en schuilgelegenheid voor insecten, en bevatten net als veel overige plantensoorten zowel plaagsoorten, neutrale herbivore soorten als plaagbestrijders.

Akkerdistel en (Krul)zuring zijn veelvoorkomende soorten die als bron van plagen en als onkruid worden ervaren. Vooral akkerdistel wordt vaak selectief gemaaid voor de bloei. Op deze soorten komen echter ook veel natuurlijke vijanden voor (roofwantsen, zweefvliegen en lieveheersbeestjes).

Roofmijten (vijand van plaagtripsen) komen op heel veel bemonsterde waardplanten voor. Deze zijn in dit onderzoek niet tot op soortniveau gedetermineerd, maar het is duidelijk dat veel roofmijten van de familie Phytoseiidae algemeen aanwezig zijn.

Als we naar typische oeverplanten kijken die zijn bemonsterd, bevatten de meeste soorten zowel plaagbestrijders, plaagsoorten als neutrale soorten. Er zijn een paar soorten zonder plaagbestrijders (Echte Valeriaan, Gele lis) of zonder plaagsoorten (Dotterbloem, Riet), maar gezien de kleine aantallen monsters kunnen we hier weinig conclusies aan verbinden.

Door de overvloedige aanwezigheid van (bloeiende) planten en waardplanten met niet-schadelijke bladluissoorten (Riet met Melige pruimenluis, Akkerdistel en Krulzuring met Aphis rumicis) in de Poelzone, konden hier ook meer bloemmonsters verzameld worden met natuurlijke vijanden van bladluis (zweefvliegen, lieveheersbeestjes, galmuggen, roofkevers, sluipwespen) dan in de regulier beheerde bermen.

\section{Vaststellen van perioden van voorkomen plaagbestrijdende en plaagsoorten}

De hoogste dichtheden van Frankliniella occidentalis (Californische trips) werden in juni-juli bereikt in de onderzochte locaties. Algemeen wordt aangenomen dat deze trips niet overwintert buiten kassen. Het kan dus zijn dat de eerste tripsen in april afkomstig waren van invlieg vanuit kassen naar de berm, waar ze zich vervolgens hebben kunnen vermeerderen. De grote dichtheden van natuurlijke populaties van Orius niger die tegelijkertijd verschijnen, heeft de dichtheden waarschijnlijk helpen onderdrukken, evenals de natuurlijke aanwezigheid van roofmijten.

Voor bladluizen en hun natuurlijke vijanden is het seizoensbeeld wat lastiger, omdat er veel verschillende soorten plaagbestrijders zijn en er slechts één soort bladluis tot op soortniveau gedetermineerd kon worden. De meeste bladluizen hebben hun maximale aantal monsters in juli, terwijl de natuurlijke vijanden hun maximale aantal monsters in juni, juli of augustus hebben.

\section{Aanvullende waarnemingen insecten en waardplanten beschrijven}

Uit losse waarnemingen viel op te merken dat in de Poelzone veel bladluisbestrijders leven die zich voeden met niet-plaagsoorten bladluis die een goede voedselvoorraad (bankersysteem) vormen voor de natuurlijke vijanden. Ook hier is Akkerdistel een belangrijke soort voor zowel plaaginsecten als plaagbestrijders.

\section{Vergelijken perioden voorkomen van plaaginsecten in Poelzone, bermen en kassen}

Van een van de tuinders is een enquêteformulier ontvangen met waargenomen plagen en gebruikte methoden van plaagbestrijding. Aangezien aan de hand van waarnemingen uit één kas geen betrouwbare uitspraken gedaan kunnen worden, hebben we dit onderdeel van het onderzoek niet kunnen opnemen in deze rapportage.

\subsection{Discussie}

Bij de interpretatie van de resultaten is het goed om de volgende punten in acht te nemen:

Bij het kiezen van de locaties is geprobeerd voor elke locatie onderscheid te maken in oevers en droge delen. In de bermen langs de provinciale weg kwamen echter geen oevers voor en langs de 
Julianaweg zijn er alleen oevers van sloten. Deze zijn zeer verschillend van karakter vergeleken met de oeverzones langs de Poelzone. Ook bestaan alle locaties in de Poelzone uit een droog en een oeverdeel, in de bermen is dat alleen het geval in B1 en B2. De lengtes van de geinventariseerde transecten zijn overal wel gelijk (50 m).

Het aantal monsters is niet gelijk in alle locaties. In de Poelzone zijn 137 monsters verzameld, grotendeels bloemmonsters, en in de bermen 62. Dat komt omdat in de Poelzone meer soorten waardplanten voorkomen; deze konden niet worden gemonsterd in de bermen.

De gebruikte vangmethoden (bloemen bemonsteren en vangnetmonsters) zijn niet voor alle soorten insecten geschikt. Spinnen werden wel in vangnetmonsters gevonden, maar deze zijn niet gedetermineerd. Bovendien kunnen ze niet van bermen naar kassen migreren. Ook sluipwespen werden veelvuldig in vangnetmonsters aangetroffen, maar ook deze zijn niet op naam gebracht. Dit is erg lastig zonder te weten welke gastheren bij de sluipwespen horen. De plaaginsecten Witte vlieg, mineervlieg en spint zijn niet aangetroffen in de bemonsteringen. Niet alle insecten konden tot op soortniveau worden gedetermineerd. Van een aantal tripsen is (nog) niet bekend of ze schadelijk zijn of niet.

Door de grote soortenrijkdom aan waardplanten is slechts een klein deel van alle aangetroffen planten bemonsterd en de meeste plantensoorten slechts enkele malen. Zo zijn er van de 35 typische oeverplanten slechts 9 soorten bemonsterd. Er zijn geen grassen bemonsterd, alleen riet. Het is goed mogelijk dat er ook grastripsen aanwezig waren, maar deze zijn niet bemonsterd. Het is bekend dat sommige grastripsen ook kassen binnenvliegen, maar deze soorten zijn waardplant-specifiek en vormen geen bedreiging voor de gangbare kasteelten. Er zijn wel oeverplanten bemonsterd, maar geen waterplanten. Het beeld van insecten in de oevers is daarom wellicht verre van compleet.

$\mathrm{Er}$ is op de data geen uitgebreide statistische analyse gedaan. Wel zijn de aantallen tripsen in de Poelzone en bermen (tabel 3.4 en 3.5) getoetst, maar significante verschillen zijn niet aangetroffen, waarschijnlijk door het kleine aantal te toetsen soorten insecten. Een analyse per soort insect op het aantal monsters waarin ze voorkomen in de Poelzone en in de bermen is in principe mogelijk, maar lastig door het verschillende aantal monsters in beide locaties, de verschillende soorten waardplanten in deze monsters en het lage aantal waarnemingen van veel gevonden soorten per waardplant (veel nul-waarnemingen leiden tot een niet-normale verdeling van waarden).

2018 was een bijzonder droog jaar, wat gevolgen kan hebben gehad op het voorkomen van waardplanten en insecten. Het kan dus zijn dat resultaten in andere jaren afwijken.

Er moet nog wel worden nagegaan in hoeverre de vegetatie, de gebruikte grasmengsels en beheer en dus ook de te verwachten (plaag en -bestrijdende) insecten en waardplanten in de Poelzone overeenkomen met die van andere natuurlijk beheerde (provinciale) wegbermen buiten de onderzochte locaties elders in Nederland, en in hoeverre deze factoren variëren in regulier beheerde wegbermen binnen Nederland. Dit geldt ook voor de gebruikte zaadmengsels en oevermatten. Ook is het de vraag of een groot gebied als de Poelzone representatief is voor natuurlijk beheerde wegbermen en andere oevers, die vaak veel smaller zijn en dus minder divers.

Het onderzoek concentreert zich op insecten die belangrijk zijn voor gewasbescherming. Er zijn echter veel zweefvliegen gevonden die een bijdrage aan bestuiving leveren. Dit aspect is niet meegenomen in dit onderzoek.

In dit onderzoek hebben we geen waarnemingen uit kassen kunnen gebruiken. Het vergelijken van de locatie en het tijdstip van waargenomen (plaag)insecten in de kas met die in de omliggende bermen en de Poelzone is echter een belangrijke methode om vast te kunnen stellen of er überhaupt dezelfde plaagsoorten in de kas en omliggende bermen/Poelzone voorkomen en of de periode waarin ze voorkomen, overeenkomen. 


\subsection{Aanbevelingen}

\section{Aanbevelingen ten aanzien van beheer}

Aanbevelingen ten aanzien van het beheer zijn nog lastig te geven, omdat dit onderzoek is gebaseerd op een beperkt aantal herhalingen (van bemonsterde waardplanten en vangnetmonsters) per locatie, terwijl het aantal herhalingen ook nog verschillend is per waardplant en per (deel)locatie. Ook beslaat het onderzoek slechts één (droog) seizoen en slechts in één gebied. Wel zijn de twee typen beheer in elk vier locaties vergeleken, waaruit ten aanzien van beheer het volgende kan worden aangegeven:

Aangezien het evenwicht tussen soorten van plaaginsecten, niet-plaaginsecten en natuurlijke vijanden iets beter is in de natuurlijk beheerde Poelzone dan in de regulier beheerde bermen, lijkt het voor het reduceren van de plaagdruk niet zinvol om natuurlijk beheer in de Poelzone te vervangen door het reguliere beheer in de bermen. Zowel regulier als natuurlijk beheer kan niet voorkomen dat er überhaupt plaagsoorten voorkomen in de bermen en in de Poelzone. Ook moet opgemerkt worden dat de verschillen in beheer tussen bermen en de Poelzone niet heel erg groot zijn. De bermen langs de provinciale weg worden (nu nog) geklepeld, maar de bermen langs de Julianaweg worden ook gemaaid met afvoeren van maaisel (zie tabel 2.2).

Omdat plaaginsecten en plaagbestrijders op veel verschillende waardplanten voorkomen en natuurlijke plaagbestrijders op dezelfde waardplanten voorkomen als de plaagsoorten, lijkt het niet zinvol om selectief waardplanten voor de bloei te maaien om verspreiding van plaaginsecten te voorkomen. Het kan wel zaadverspreiding van ongewenste planten tegengaan.

\section{Aanbevelingen ten aanzien van vervolgonderzoek}

We hebben het voorkomen van plaaginsecten in de kas en in het veld slechts voor één bedrijf kunnen vergelijken in 2018. Het verdient aanbeveling om dit voor meer kassen in de omgeving alsnog te doen met data van 2018. Daarbij kan dan ook informatie over verspreiding van (on)kruiden opgevraagd worden.

We hebben in dit onderzoek alleen naar het voorkomen van plaaginsecten en plaagbestrijders gekeken, maar niet kunnen constateren of plaagsoorten (en natuurlijke vijanden) zich van bermen of Poelzone naar kassen bewegen of van kassen naar Poelzone of bermen en hoe dit kan plaatsvinden. Ook is niet bekend welke invloed dit heeft op de productie van gewassen in glastuinbouwbedrijven Hier is vervolgonderzoek voor nodig.

Dit onderzoek geeft een algemene indruk van de situatie in en rond de Poelzone en is gericht op de belangrijkste bekende plaaginsecten in kassen, hun waardplanten en hun natuurlijke bestrijders. Om betere (statistisch onderbouwde) uitspraken te doen over de relatie tussen (berm)beheer en voorkomende plaag(bestrijdende) insectenpopulaties, is het aan te bevelen om (meerjarig) onderzoek op te zetten in meerdere gebieden, waar op vergelijkbare wijze wordt geïnventariseerd en waar ook een vergelijking wordt gemaakt van voorkomende plaaginsecten in de glastuinbouwbedrijven. Hierbij is het aan te bevelen om binnen elke locatie twee beheervarianten toe te passen en die te vergelijken. Ook is het aan te bevelen om dan technieken toe te passen waarmee de nu onderbelichte groepen zoals spinnen, loopkevers en sluipwespen ook gemonitord kunnen worden. Met deze technieken kunnen niet alleen hogere aantallen van al aangetroffen soorten worden gevangen, maar ook soorten die nu nog geheel ontbreken in de monsters. Potvallen en pyramidevallen kunnen hier toegepast worden. Plakstrips en vangplaten zijn wellicht een iets minder selectieve vangmethode voor vliegende soorten dan vangnetten. 


\section{Dankwoord}

Dit onderzoek is uitgevoerd in opdracht van de gemeente Westland en gefinancierd door de gemeente Westland, Hoogheemraadshap van Delfland en de Provincie Zuid-Holland. We willen Bert Vierbergen van de NVWA hartelijk danken voor zijn hulp bij het identificeren van de aangetroffen tripssoorten. Ook willen we Wim Dimmers en Ruud van Kats van Wageningen Environmental Research bedanken voor het reviewen van het rapport. Ten slotte willen we Danny Tahey bedanken voor de praktische ondersteuning in het veld. 


\section{Literatuur}

Hennekens, S.M. \& Schaminee H.J.H. (2001). Turboveg, a comprehensive database management system for vegetation data Journal of Vegetation Science 12: 589-591.

Nonhof, C.J. 2017. Poelzone 2017. KNNV-rapportage afdeling Delfland, Delft. 

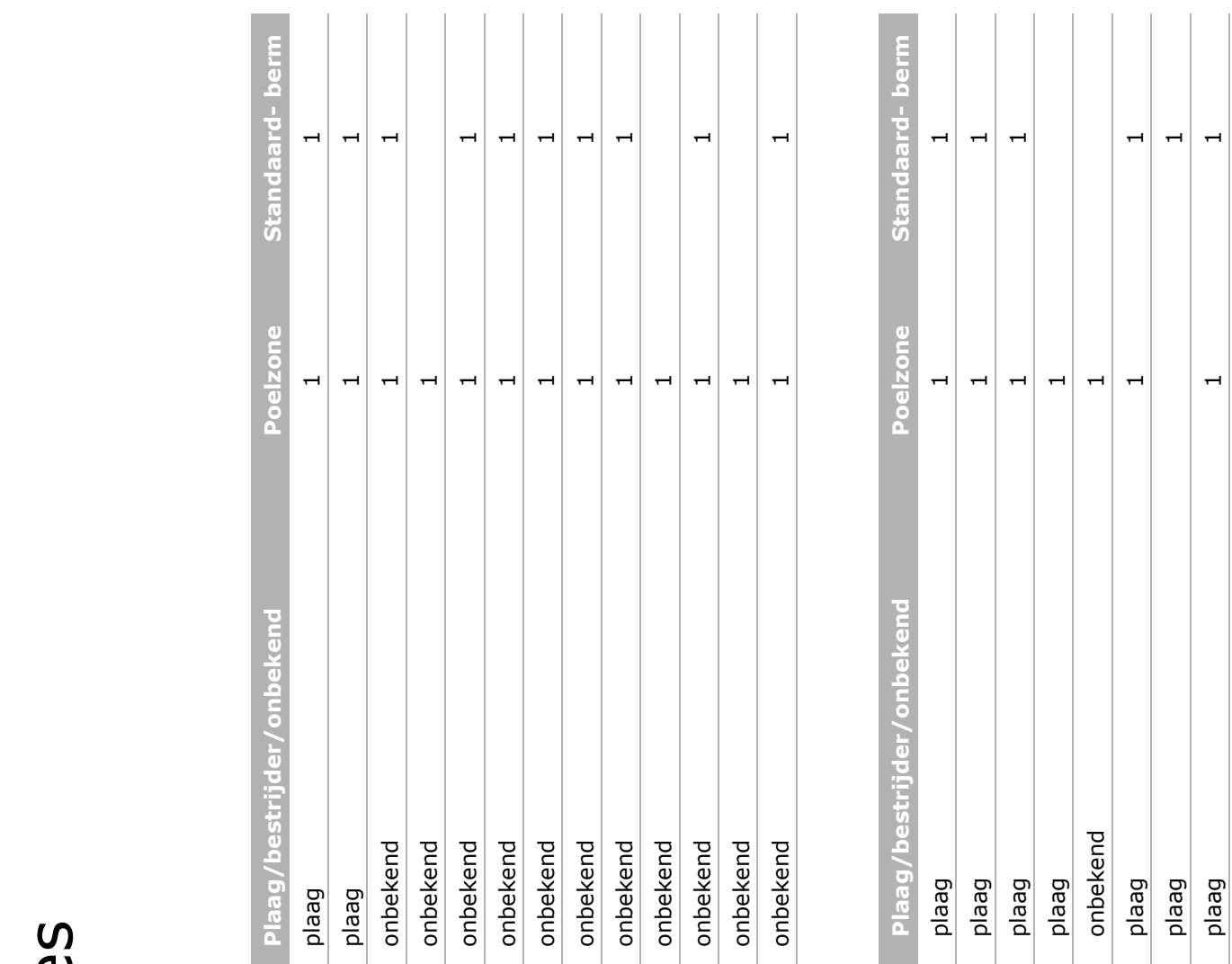

$\frac{1}{1}$

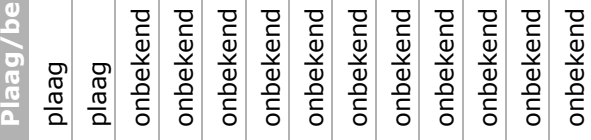

음

(1)

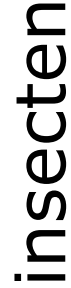

o

$\stackrel{\subseteq}{ \pm}$

T

$\frac{2}{0}$
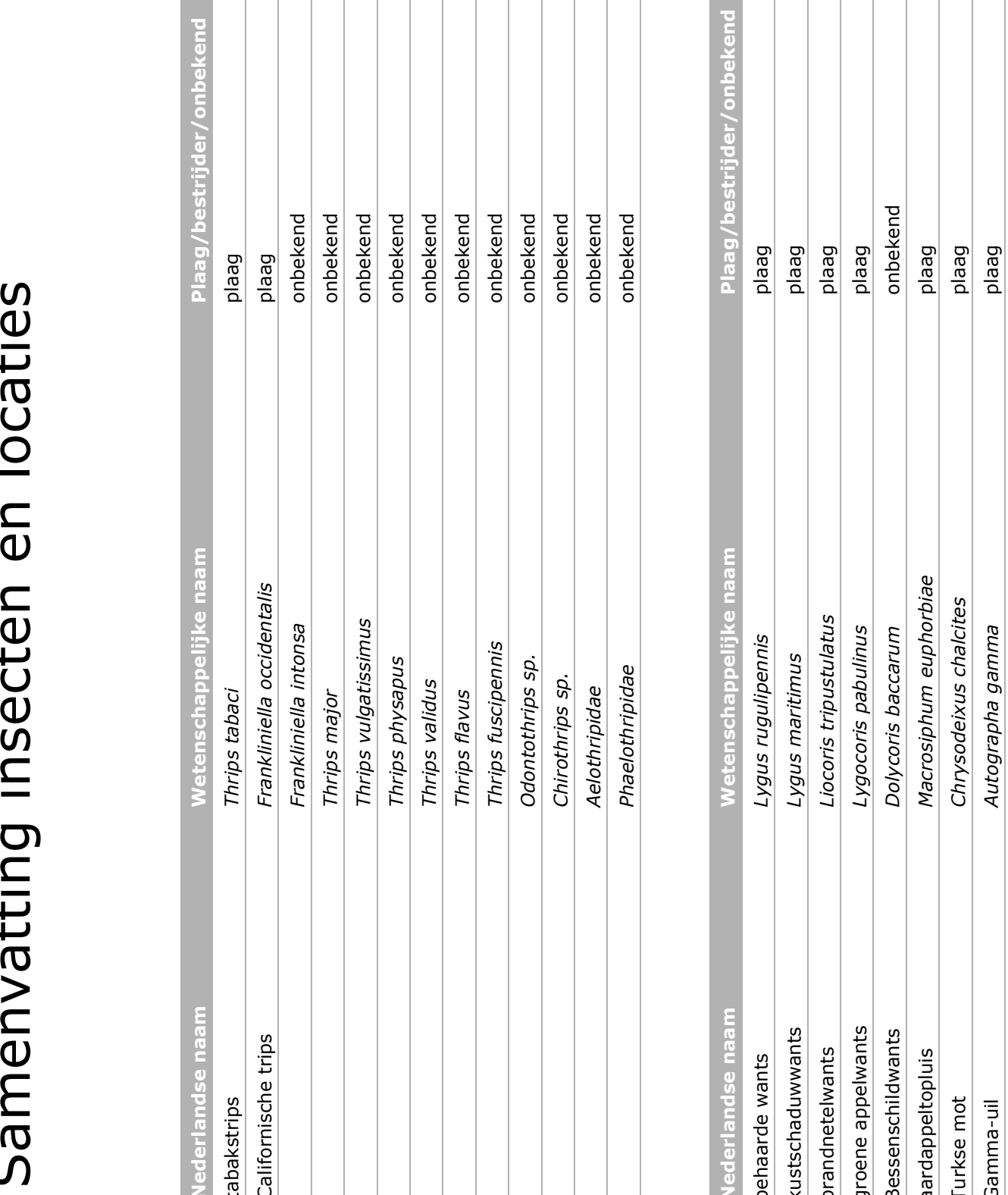

$\frac{\pi}{\pi}$
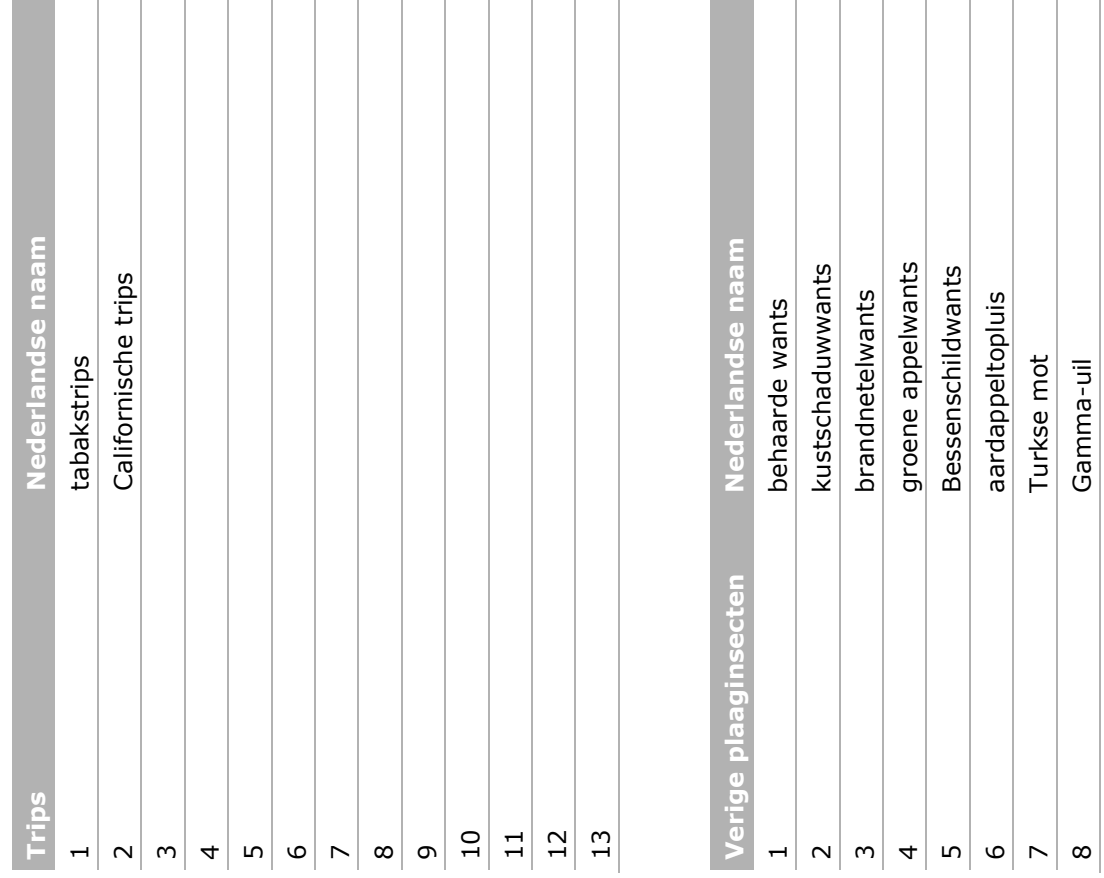


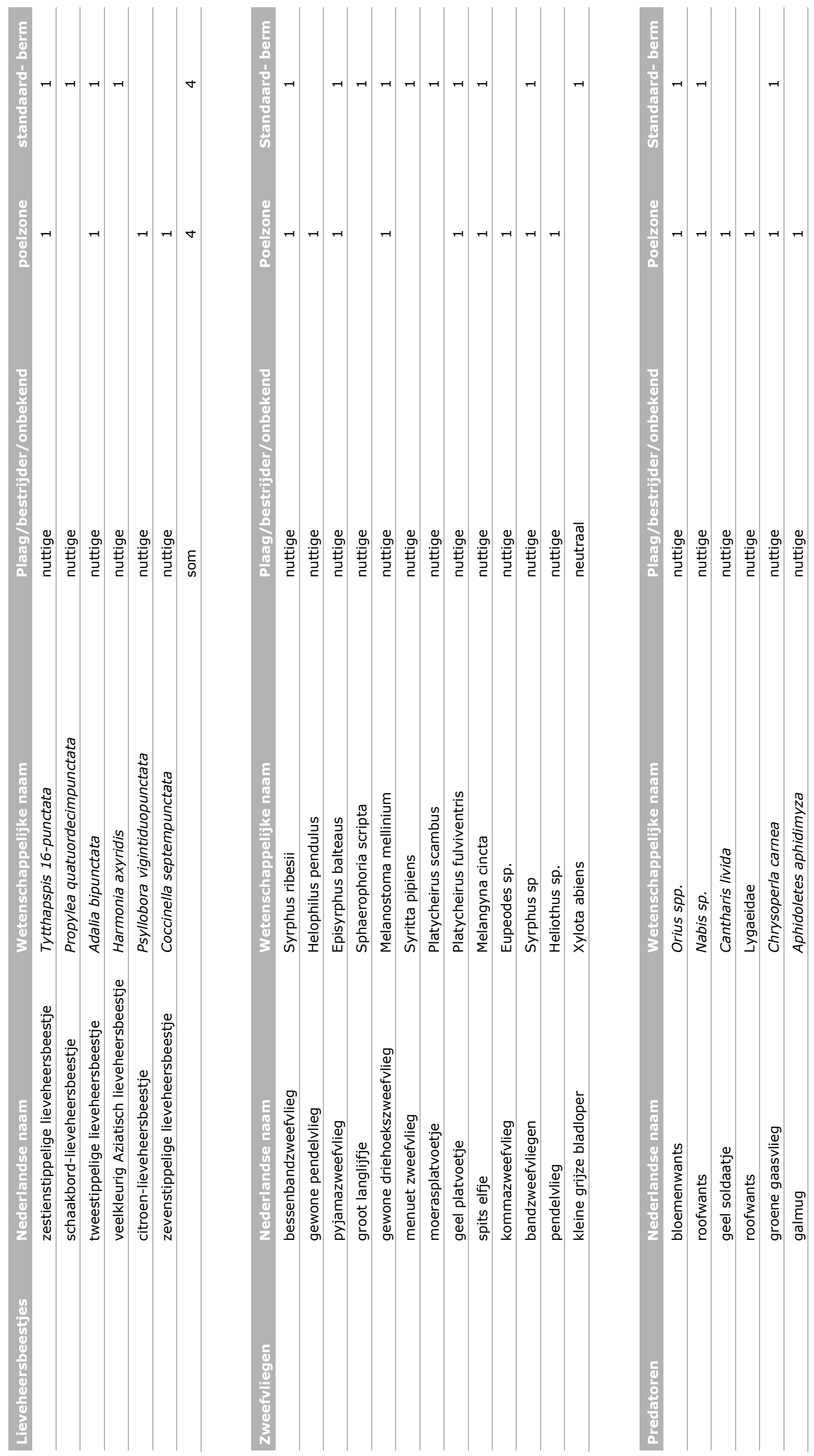




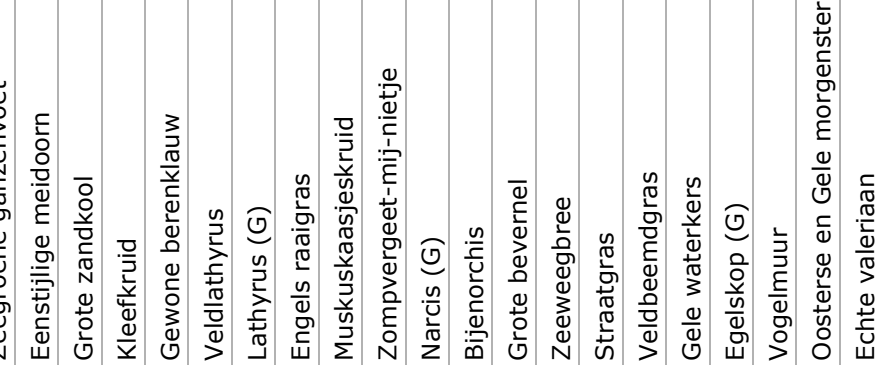

$\Xi \infty$

ఏ เ

迹

$\infty$

ณ

U
$\frac{0}{N}$
$\frac{1}{0}$
0

ณ

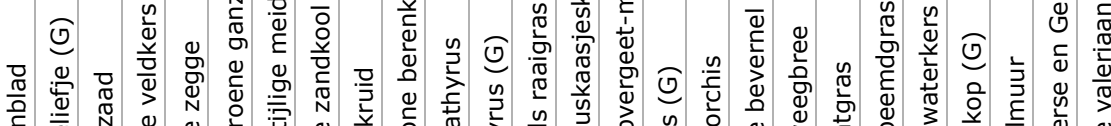

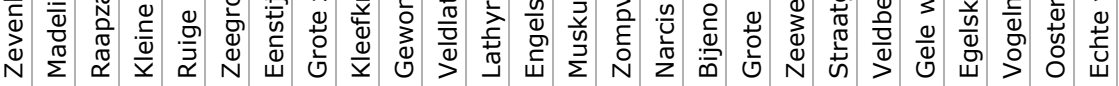

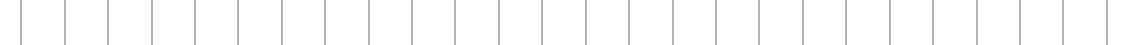

$\frac{5}{2}$

2 in

ล

(1)

$-1+\infty$

$\frac{1}{\varepsilon}$

- 1 in

공

if $\infty$

in $x$

$\frac{x}{4+4} \times$

\begin{tabular}{|l}
$x$ \\
$x$ \\
$x$
\end{tabular}

$\stackrel{x}{x}$

.

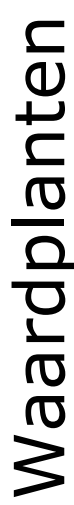

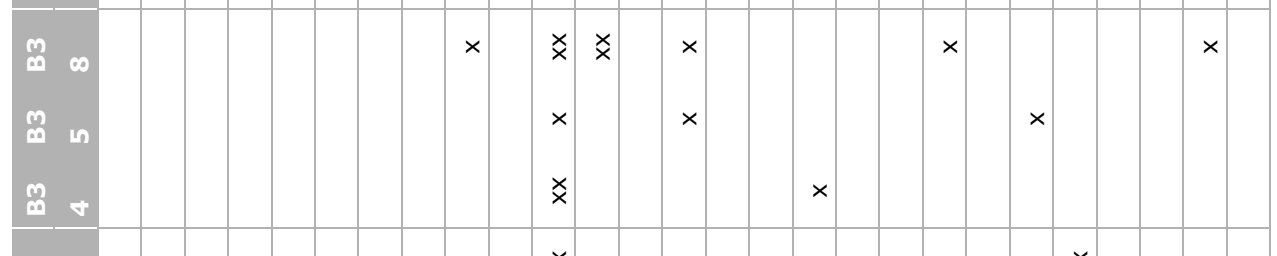

N

$\frac{0}{0} \frac{\pi}{\pi}$

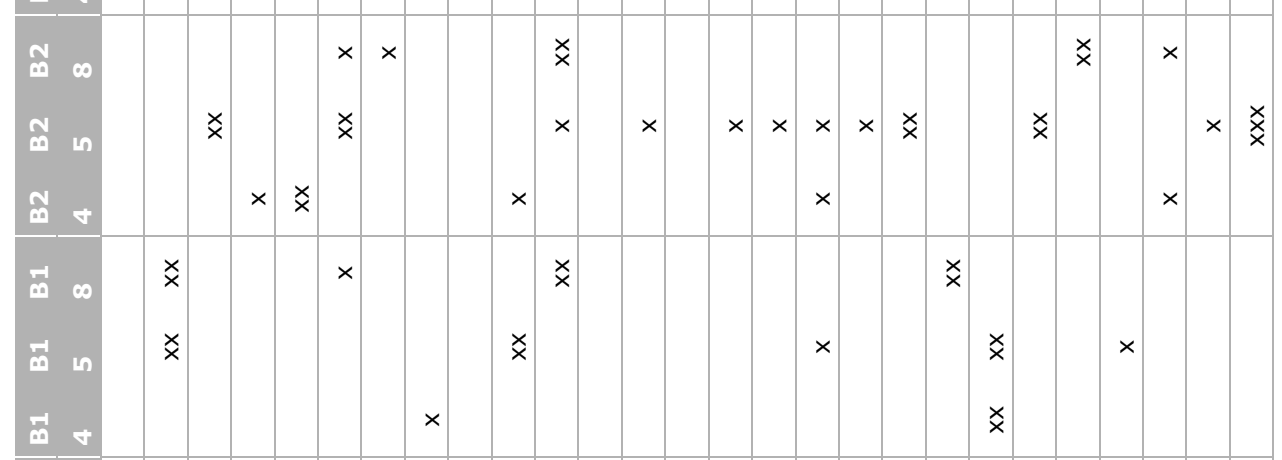

뭉

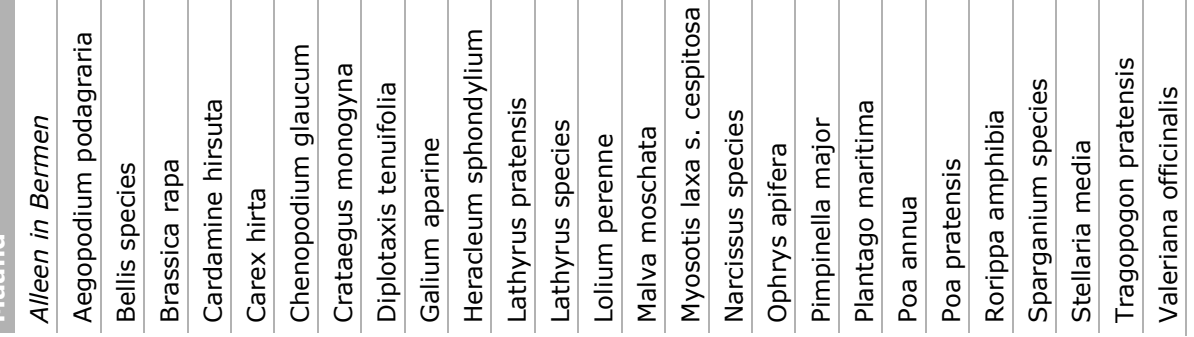




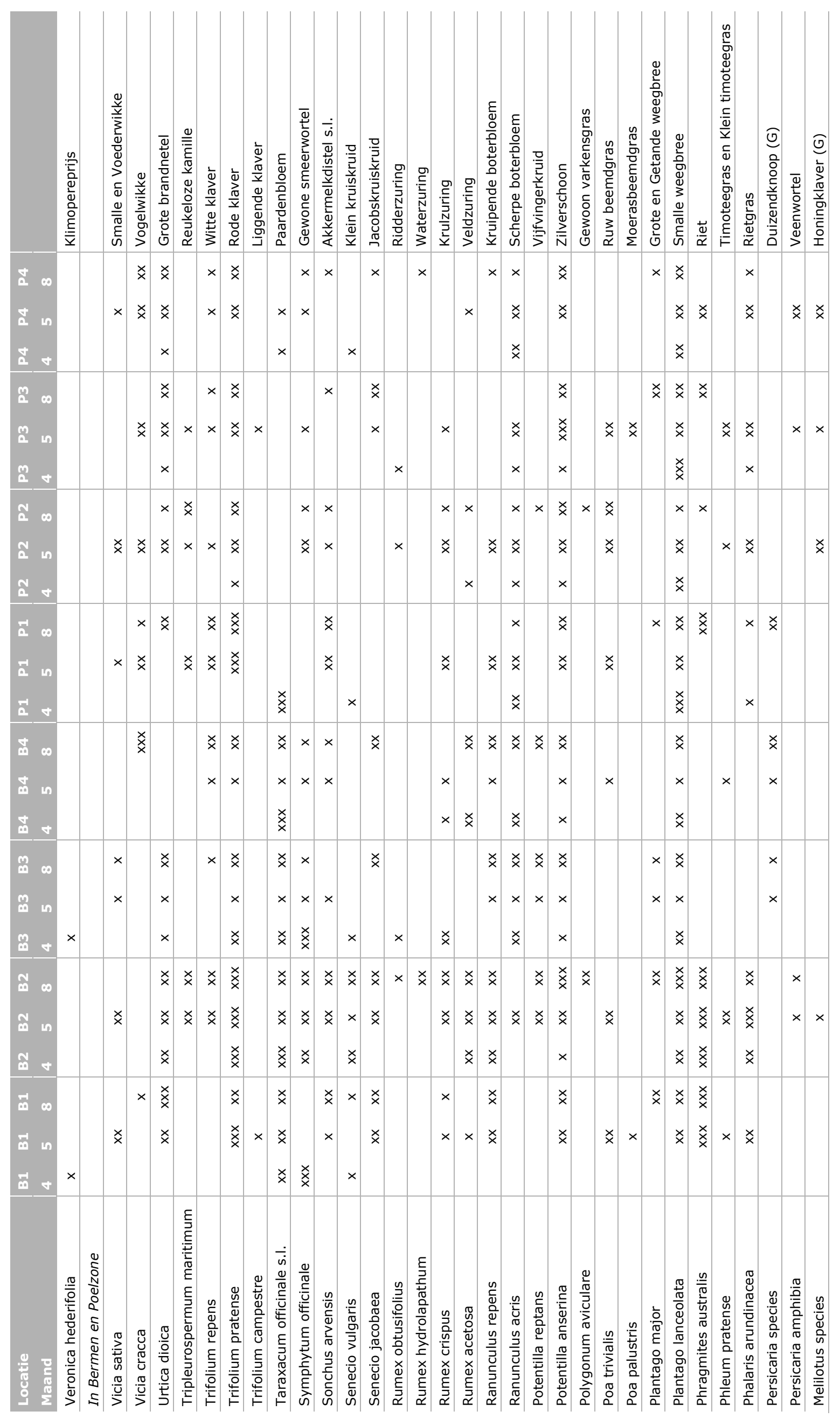




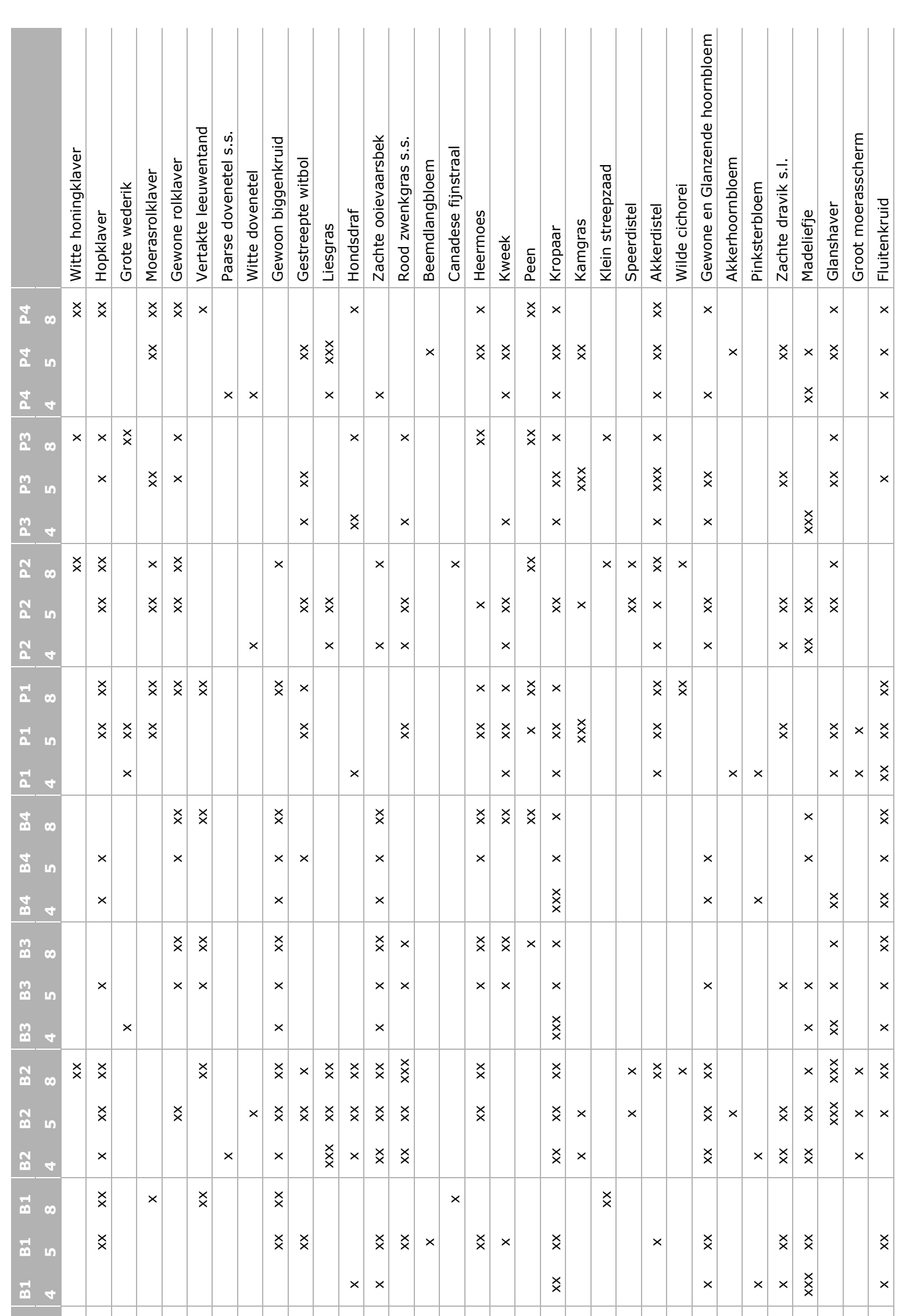

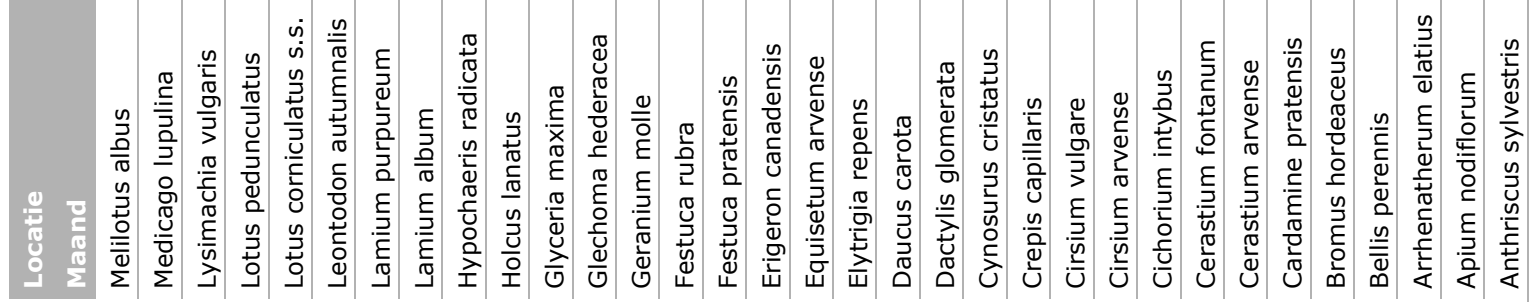




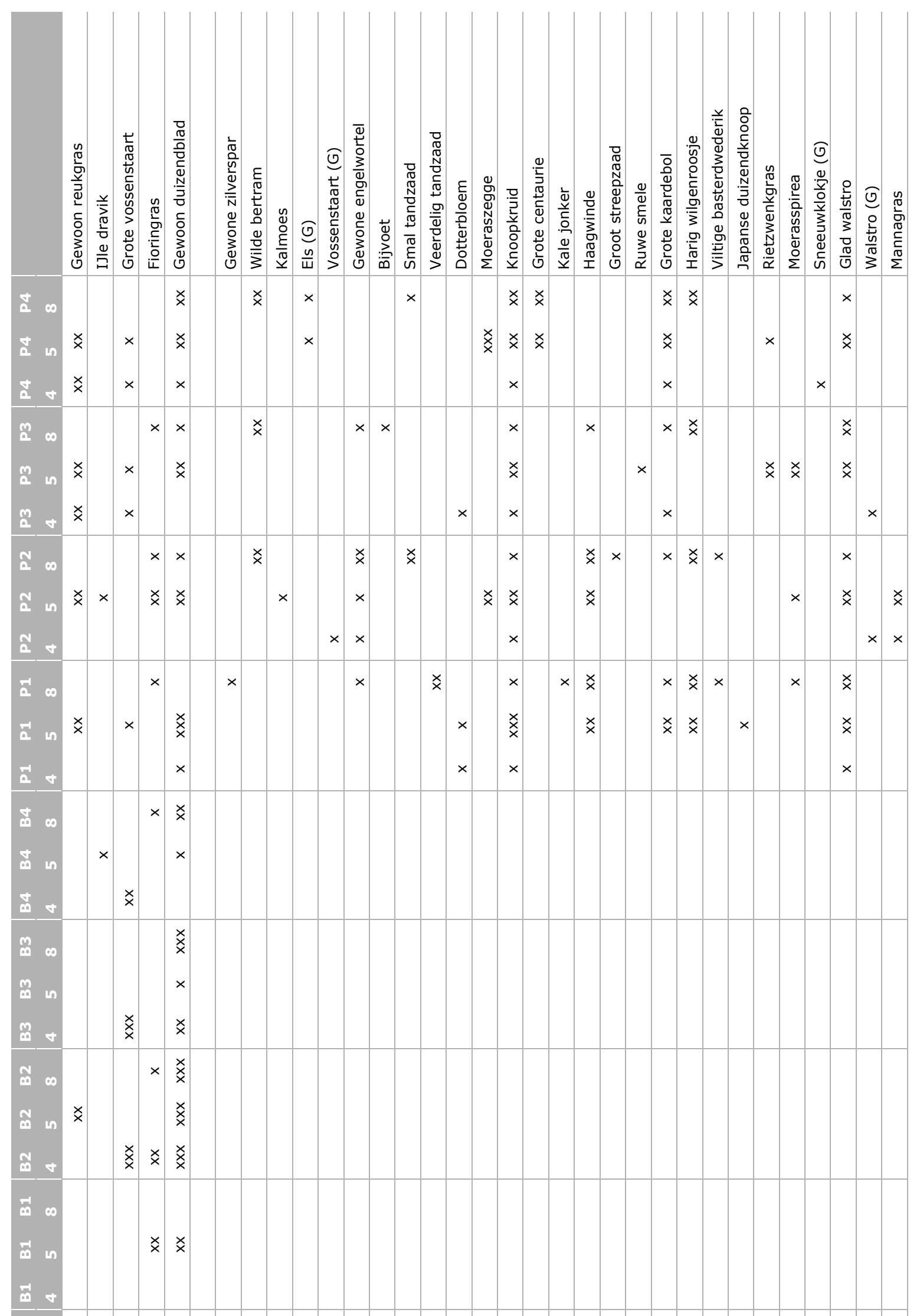

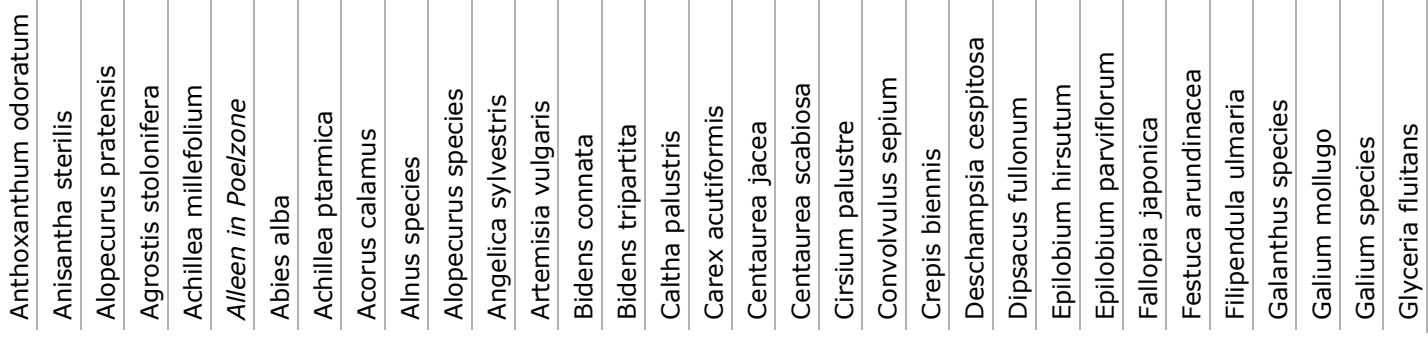




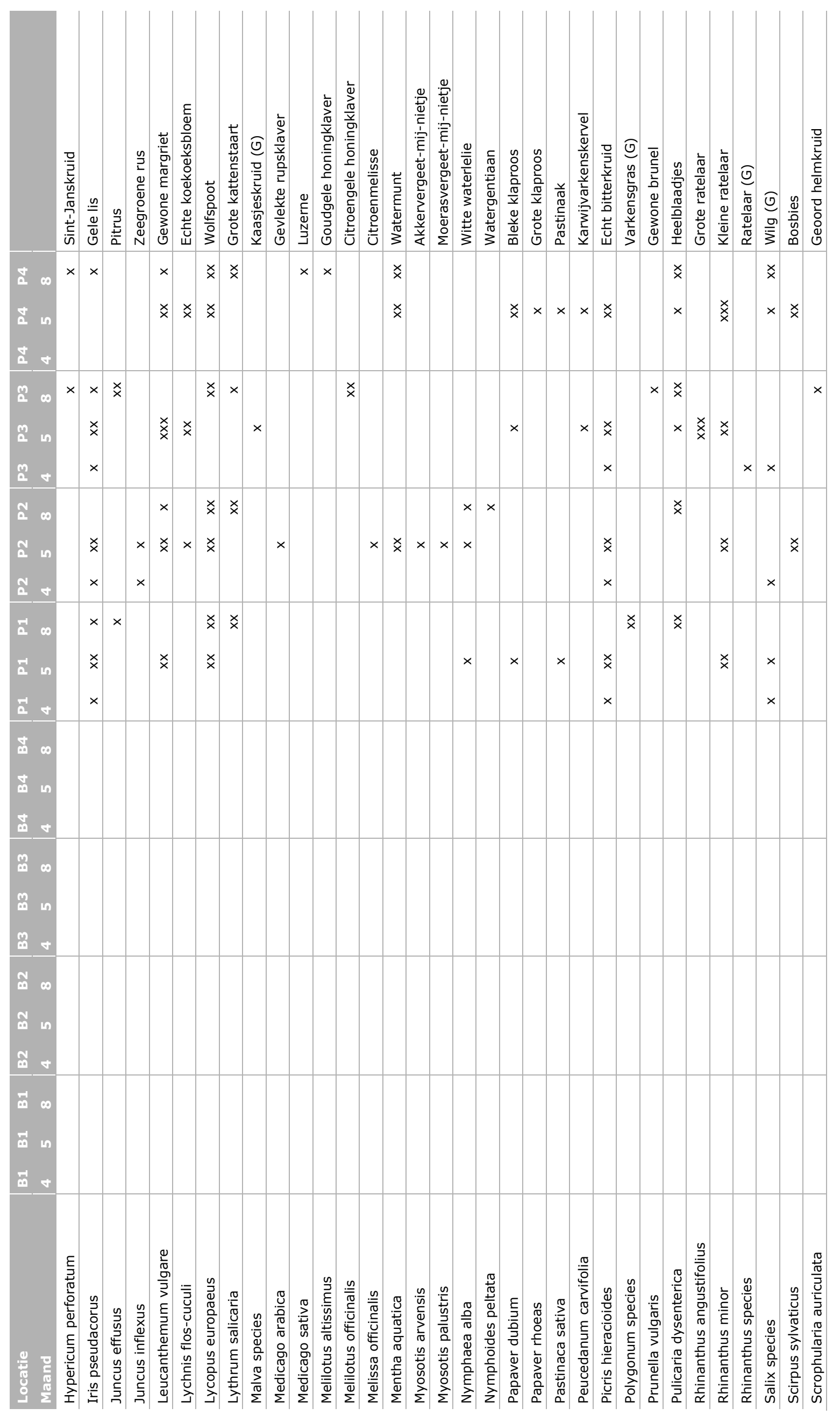




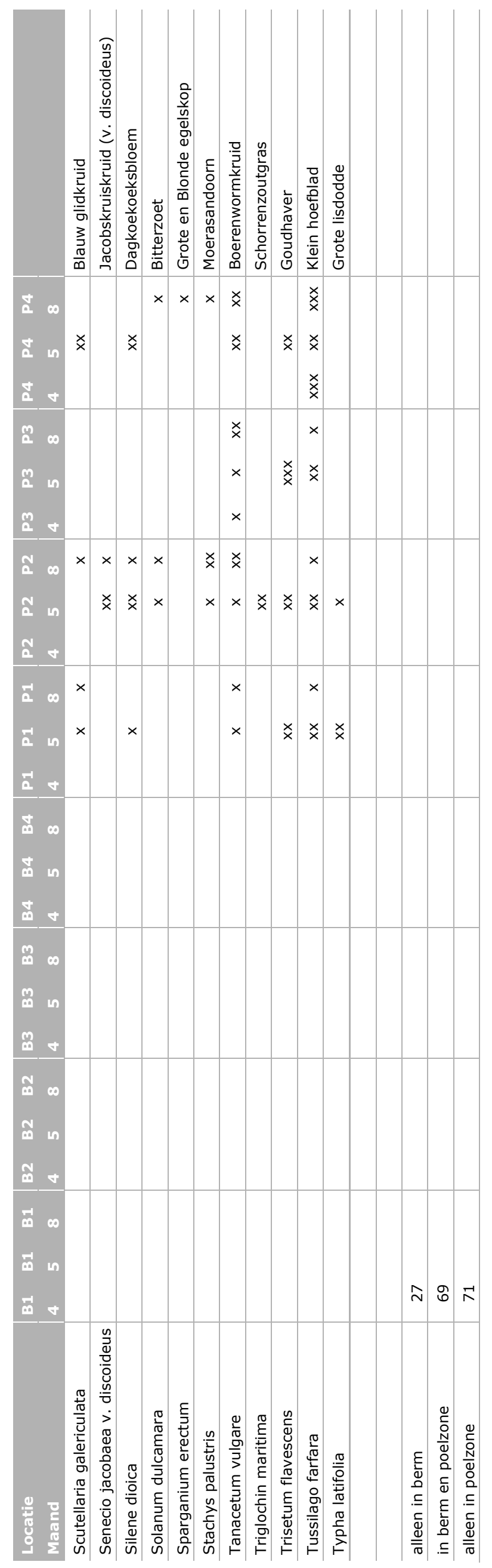

44 | Wageningen Environmental Research Rapport 2946 


\section{Bijlage 3 Insecten en waardplanten}

\begin{tabular}{|c|c|c|c|c|c|}
\hline Gemiddelde aantallen & Plaagbestrijders & Neutraal & Onbekend & Plaag & Overall \\
\hline \multicolumn{6}{|l|}{ Locaties } \\
\hline B1 & 2.23 & 42.46 & 38.08 & 4.21 & 14.27 \\
\hline B2 & 2.97 & 80.98 & 20.68 & 18.61 & 19.41 \\
\hline B3 & 2.13 & 92.75 & 95.50 & 36.82 & 37.09 \\
\hline B4 & 1.50 & 29.85 & 26.80 & 31.23 & 17.39 \\
\hline P1 & 5.01 & 9.25 & 5.49 & 3.13 & 5.21 \\
\hline P2 & 1.65 & 5.27 & 7.30 & 4.91 & 3.68 \\
\hline P3 & 2.85 & 6.72 & 7.73 & 8.12 & 5.64 \\
\hline P4 & 4.42 & 17.47 & 7.82 & 5.39 & 7.34 \\
\hline Totaal & 2.90 & 14.10 & 7.29 & 5.84 & 6.02 \\
\hline \multicolumn{6}{|l|}{ Plantensoorten } \\
\hline akkerdistel & 10.00 & 0.00 & 0.00 & 0.00 & 10.00 \\
\hline akkermelkdistel & 1.00 & 24.50 & 24.50 & 3.50 & 15.14 \\
\hline gemaaid, geen bloemen genomen & 0.00 & 0.00 & 0.00 & 0.00 & \\
\hline biggenkruid & 0.00 & 11.00 & 6.00 & 1.50 & 6.20 \\
\hline boerenwormkruid & 3.50 & 1.50 & 6.50 & 11.17 & 6.63 \\
\hline boterbloem & 1.00 & 2.50 & 1.00 & 1.00 & 1.60 \\
\hline citroengele honingklaver & 0.00 & 1.50 & 6.00 & 1.17 & 2.08 \\
\hline dotterbloem & 4.00 & 1.00 & 0.00 & 0.00 & 2.50 \\
\hline duizendblad & 4.00 & 5.75 & 12.90 & 30.11 & 16.45 \\
\hline duizendblad, fluitenkruid, wilde peen? & 2.00 & 1.00 & 20.00 & 11.00 & 9.00 \\
\hline echt bitterkruid & 0.00 & 4.98 & 3.67 & 0.00 & 4.72 \\
\hline echte valeriaan & 0.00 & 1.00 & 1.00 & 116.50 & 47.20 \\
\hline fluitenkruid & 1.00 & 0.00 & 0.00 & 0.00 & 1.00 \\
\hline gele lis & 0.00 & 0.00 & 1.00 & 0.00 & 1.00 \\
\hline \multicolumn{6}{|l|}{ gemaaid, alleen vangnetmonster } \\
\hline gewone berenklauw & 1.00 & 2.00 & 3.50 & 30.75 & 13.60 \\
\hline gewone rolklaver & 0.00 & 0.00 & 5.00 & 0.00 & 5.00 \\
\hline gewone smeerwortel & 0.00 & 2.50 & 4.00 & 2.00 & 2.75 \\
\hline glad walstro & 0.00 & 0.00 & 4.00 & 2.00 & 3.00 \\
\hline grote centaurie & 3.00 & 22.39 & 2.25 & 6.33 & 11.57 \\
\hline grote ratelaar & 1.00 & 3.00 & 2.00 & 8.75 & 4.70 \\
\hline grote walstro & 0.00 & 2.00 & 1.00 & 5.00 & 2.50 \\
\hline grote wederik & 2.00 & 1.00 & 98.00 & 1.00 & 25.50 \\
\hline grote zandkool & 0.00 & 0.00 & 21.00 & 75.50 & 57.33 \\
\hline harig wilgenroosje & 5.17 & 5.20 & 7.33 & 7.75 & 6.43 \\
\hline heelblaadjes & 3.33 & 5.58 & 10.75 & 10.75 & 7.72 \\
\hline herfstleeuwentand & 1.33 & 298.83 & 243.40 & 146.25 & 159.60 \\
\hline hondsdraf & 4.25 & 45.00 & 73.50 & 5.67 & 32.28 \\
\hline Jacobskruiskruid & 3.25 & 14.69 & 56.67 & 59.04 & 35.48 \\
\hline kattenstaart & 1.50 & 0.00 & 6.00 & 6.00 & 3.75 \\
\hline kleine hoefblad & 0.00 & 3.50 & 0.00 & 0.00 & 3.50 \\
\hline knoopkruid & 2.67 & 7.50 & 3.17 & 22.67 & 10.70 \\
\hline kruipende boterbloem & 0.00 & 2.67 & 19.60 & 1.00 & 4.93 \\
\hline krulzuring & 10.00 & 5.50 & 1.00 & 70.50 & 27.17 \\
\hline madelief & 1.00 & 3.50 & 5.75 & 8.50 & 4.69 \\
\hline madelief & 0.00 & 4.50 & 4.00 & 2.00 & 3.17 \\
\hline margriet & 2.00 & 1.50 & 2.23 & 9.75 & 4.58 \\
\hline moeras/gewone rolklaver & 1.00 & 24.00 & 9.00 & 5.00 & 9.60 \\
\hline moerasrolklaver & 3.00 & 4.00 & 6.00 & 0.00 & 4.33 \\
\hline moerasrolklaver & 0.00 & 2.00 & 1.00 & 2.00 & 1.67 \\
\hline orchis & 1.00 & 4.00 & 0.00 & 19.00 & 8.00 \\
\hline
\end{tabular}




\begin{tabular}{|c|c|c|c|c|c|}
\hline Gemiddelde aantallen & Plaagbestrijders & Neutraal & Onbekend & Plaag & Overall \\
\hline paardenbloem & 1.00 & 1.17 & 1.00 & 16.00 & 2.72 \\
\hline reukeloze kamille & 2.25 & 14.50 & 72.67 & 17.00 & 18.62 \\
\hline reukgras & 0.00 & 0.00 & 0.00 & 1.00 & 1.00 \\
\hline riet & 10.00 & 10.00 & 0.00 & 0.00 & 10.00 \\
\hline rode klaver & 5.30 & 13.77 & 12.43 & 5.13 & 8.07 \\
\hline rode klaver & 0.00 & 5.00 & 0.00 & 0.00 & 5.00 \\
\hline scherpe boterbloem & 0.00 & 2.50 & 3.60 & 6.00 & 3.64 \\
\hline scherpe boterbloem & 0.00 & 3.00 & 0.00 & 1.00 & 2.00 \\
\hline schijnkamille & 0.00 & 1.00 & 10.00 & 2.00 & 3.50 \\
\hline speerdistel & 2.00 & 13.00 & 5.50 & 0.00 & 7.10 \\
\hline vegetatie (vangnetmonster) & 2.51 & 1.00 & 0.00 & 2.13 & 2.35 \\
\hline veldlathyrus & 0.00 & 1.00 & 3.00 & 1.00 & 1.67 \\
\hline vogelwikke & 1.33 & 2.00 & 3.00 & 3.50 & 2.81 \\
\hline watermunt & 4.75 & 2.00 & 1.00 & 4.00 & 3.30 \\
\hline wilde bertram & 2.00 & 3.17 & 17.88 & 7.94 & 7.36 \\
\hline wilde cichorei & 0.00 & 30.58 & 39.25 & 6.94 & 22.80 \\
\hline wilde peen & 1.50 & 0.00 & 16.00 & 0.00 & 6.33 \\
\hline witte dovenetel & 0.00 & 0.00 & 0.00 & 1.00 & 1.00 \\
\hline witte en gele honingklaver & 6.00 & 0.00 & 17.50 & 5.00 & 9.50 \\
\hline witte honingklaver & 1.00 & 3.00 & 2.67 & 0.00 & 2.22 \\
\hline witte klaver & 0.00 & 1.00 & 1.00 & 0.00 & 1.00 \\
\hline witte klaver & 0.00 & 0.00 & 3.00 & 9.67 & 8.00 \\
\hline zilverschoon & 1.50 & 2.00 & 49.00 & 3.00 & 13.88 \\
\hline Totaal & 1.50 & 14.10 & 7.29 & 5.84 & 6.02 \\
\hline \multicolumn{6}{|l|}{ Maand } \\
\hline April & 1.39 & 2.72 & 3.75 & 3.23 & 2.07 \\
\hline Mei & 3.40 & 5.04 & 2.81 & 5.18 & 4.26 \\
\hline Juni & 1.63 & 3.20 & 2.71 & 7.37 & 3.70 \\
\hline Juli & 4.86 & 17.14 & 13.35 & 10.26 & 10.17 \\
\hline Augustus & 1.91 & 57.98 & 14.91 & 8.21 & 14.07 \\
\hline Totaal & 2.90 & 14.10 & 7.29 & 5.84 & 6.02 \\
\hline
\end{tabular}


Wageningen Environmental Research Postbus 47

6700 AA Wageningen

T 0317480700

www.wur.nl/environmental-research

Wageningen Environmental Research Rapport 2946

ISSN 1566-7197
De missie van Wageningen University \& Research is 'To explore the potential of nature to improve the quality of life'. Binnen Wageningen University \& Research bundelen Wageningen University en gespecialiseerde onderzoeksinstituten van Stichting Wageningen Research hun krachten om bij te dragen aan de oplossing van belangrijke vragen in het domein van gezonde voeding en leefomgeving. Met ongeveer 30 vestigingen, 5.000 medewerkers en 10.000 studenten behoort Wageningen University \& Research wereldwijd tot de aansprekende kennisinstellingen binnen haar domein. De integrale benadering van de vraagstukken en de samenwerking tussen verschillende disciplines vormen het hart van de unieke Wageningen aanpak. 



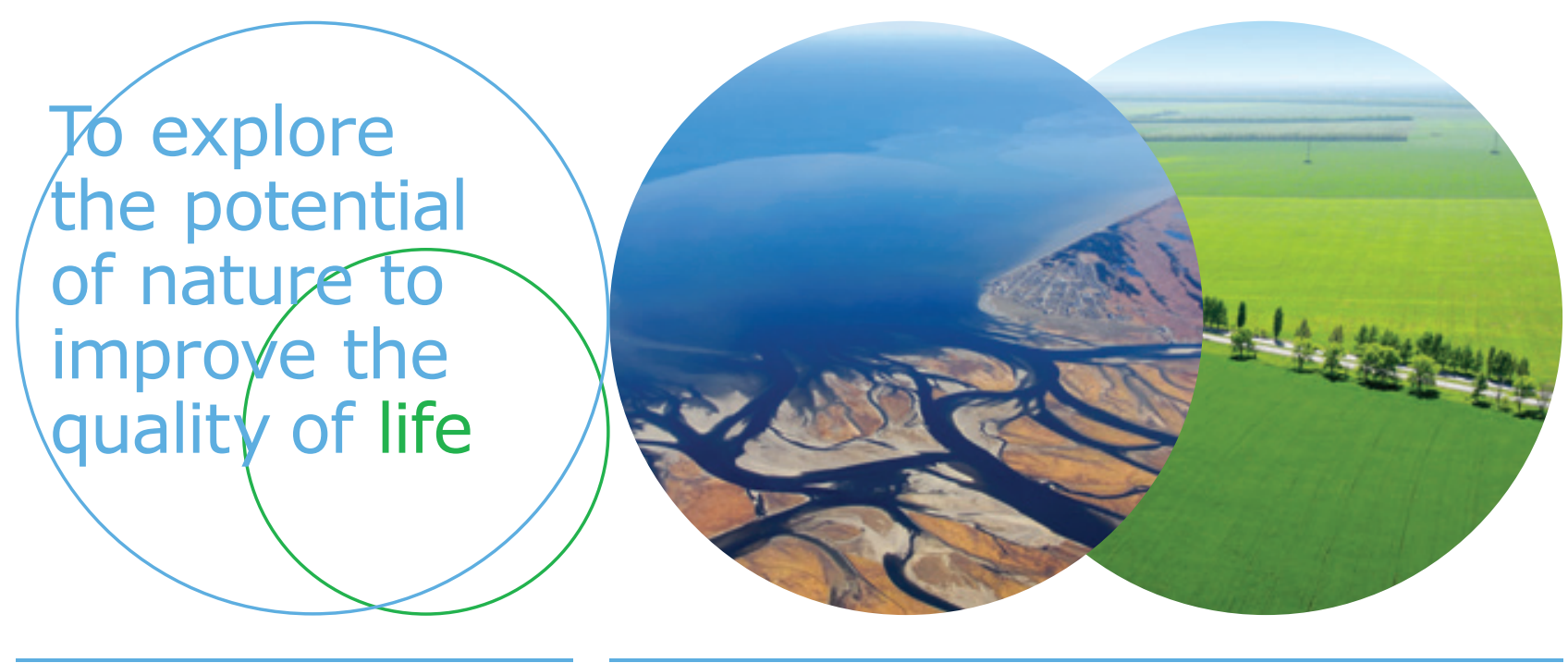

Wageningen Environmental Research Postbus 47

$6700 \mathrm{AB}$ Wageningen

T 317480700

www.wur.nl/environmental-research

Rapport 2946

ISSN 1566-7197
De missie van Wageningen University \& Research is 'To explore the potential of nature to improve the quality of life'. Binnen Wageningen University \& Research bundelen Wageningen University en gespecialiseerde onderzoeksinstituten van Stichting Wageningen Research hun krachten om bij te dragen aan de oplossing van belangrijke vragen in het domein van gezonde voeding en leefomgeving. Met ongeveer 30 vestigingen, 5.000 medewerkers en 10.000 studenten behoort Wageningen University \& Research wereldwijd tot de aansprekende kennisinstellingen binnen haar domein. De integrale benadering van de vraagstukken en de samenwerking tussen verschillende disciplines vormen het hart van de unieke Wageningen aanpak. 